\title{
Selenium Modulates Antioxidant Activity, Osmoprotectants, and Photosynthetic Efficiency of Onion under Saline Soil Conditions
}

\author{
Wael M. Semida ${ }^{1, *(\mathbb{D}}$, Taia A. Abd El-Mageed ${ }^{2}$, Abdelsattar Abdelkhalik ${ }^{1}{ }^{\mathbb{C}}$, Khaulood A. Hemida ${ }^{3}$, \\ Hamdi A. Abdurrahman ${ }^{2}(\mathbb{D})$, Saad M. Howladar ${ }^{4}$, Ahmed A. A. Leilah ${ }^{5}$ (D) and Mohamed O. A. Rady ${ }^{6}$ \\ 1 Horticulture Department, Faculty of Agriculture, Fayoum University, Fayoum 63514, Egypt; \\ aga04@fayoum.edu.eg \\ 2 Soil and Water Department, Faculty of Agriculture, Fayoum University, Fayoum 63514, Egypt; \\ taa00@fayoum.edu.eg (T.A.A.E.-M.); haa01@fayoum.edu.eg (H.A.A.) \\ 3 Botany Department, Faculty of Science, Fayoum University, Fayoum 63514, Egypt; kah00@fayoum.edu.eg \\ 4 Department of Biology, College of Science, University of Jeddah, Jeddah 21589, Saudi Arabia; \\ 04103250@uj.edu.sa \\ 5 Agronomy Department, Faculty of Agriculture, Mansoura University, Mansoura 35516, Egypt; \\ whdany2003@yahoo.com \\ 6 Agronomy Department, Faculty of Agriculture, Fayoum University, Fayoum 63514, Egypt; \\ mer00@fayoum.edu.eg \\ * Correspondence: wms00@fayoum.edu.eg; Tel.: +20-1010787788
}

Citation: Semida, W.M.; Abd El-Mageed, T.A.; Abdelkhalik, A.; Hemida, K.A.; Abdurrahman, H.A.; Howladar, S.M.; Leilah, A.A.A.; Rady, M.O.A. Selenium Modulates Antioxidant Activity,

Osmoprotectants, and Photosynthetic Efficiency of Onion under Saline Soil Conditions. Agronomy 2021, 11, 855. https://doi.org/10.3390/agronomy 11050855

Academic Editor: Alfonso Albacete

Received: 28 February 2021

Accepted: 23 April 2021

Published: 28 April 2021

Publisher's Note: MDPI stays neutral with regard to jurisdictional claims in published maps and institutional affiliations.

Copyright: (c) 2021 by the authors. Licensee MDPI, Basel, Switzerland. This article is an open access article distributed under the terms and conditions of the Creative Commons Attribution (CC BY) license (https:/ / creativecommons.org/licenses/by/ $4.0 /)$.
Abstract: Selenium (Se) has been recently reported to play a crucial role in ameliorating the negative impact of abiotic stress, including salinity, on several plant species. Two field experiments (2016/17 and 2017/18) were carried out to investigate the possible effect of exogenous Se application at two levels $\left(25,50 \mathrm{mg} \mathrm{L}^{-1}\right)$ on growth, bulb yield, physio-biochemical attributes, and antioxidant activities of onion grown under saline $\left(5.25 \mathrm{dS} \mathrm{m}^{-1}\right)$ soil condition. Se $\left(25\right.$ or $\left.50 \mathrm{mg} \mathrm{L}^{-1}\right)$ foliar application enhanced growth characteristics, as well as membrane stability index (MSI) and relative water content (RWC) as a result of the osmotic adjustment by accumulating more osmoprotectants and enhancing the activity of antioxidants defense system, thus improving photosynthetic efficiency and bulb yield. Proline, glycine betaine, choline, and total soluble sugars content were higher in leaves and bulbs of Se-treated plants under salt stress. Se $\left(25\right.$ or $\left.50 \mathrm{mg} \mathrm{L}^{-1}\right)$ significantly increased the activities of enzymatic (ascorbate peroxidase, superoxide dismutase, and catalase) and non-enzymatic (ascorbic acid and glutathione) antioxidants in both leaves and bulbs of salt-stressed onion. Se application at 25-50 $\mathrm{mg} \mathrm{L}^{-1}$ may find, in the future, a potential application as anti-abiotic stresses for improving plant growth and productivity under saline soil condition.

Keywords: Allium cepa; selenium, salinity stress; antioxidant activities; osmoprotectants; photosynthetic efficiency

\section{Introduction}

Onion (Allium cepa L.) is the second most broadly cultivated vegetable crop in the world for their economic importance, nutritional value, flavor, and medicinal properties [1]. In 2019, worldwide bulb onion production was approximately 100 million tons harvested from an area of approximately 5.2 million ha. Onion cultivated area in Egypt was 87,948 ha and produced 3.08 million tons. Among the main countries exporting onion, Egypt ranked fourth after China, India, and United States of America [2]. Onion is deemed to be a salt-sensitive crop, with a salinity threshold level of around $1.2 \mathrm{dS} \mathrm{m}^{-1}$ for bulb yield [3]. For every increase in ECe unit, onion bulb yield proportionally reduces [4,5].

Salinity is a major abiotic stress threatening crop production especially in arid/semiarid areas including Egypt. Salt-affected soils are estimated to be $20-33 \%$ of the world's 
cultivated and irrigated soils and, with lower rainfall, higher evaporation, and poor cultural practices, the salinized areas are predicted to reach $50 \%$ by 2050 [6-8].

Besides its impact on the imbalance of nutrients, salinity contributes to the reduction of plant osmotic potential leading to water stress and a buildup of excessive amounts of ions in plant tissues to a potentially toxic level $[7,9,10]$. Therefore, salinity induces various morphological, physiological, and biochemical alterations in plant tissues, including ion homeostasis disturbance, downregulation of photosynthetic pigments, and diminish the photosynthesis efficiency, due to minimizing the activity of photosystem II (PSII) [11,12], and decreasing stomatal conductance and $\mathrm{CO}_{2}$ uptake [13], which ultimately hinder plant growth and productivity. A common response to abiotic stresses including salinity is the hyper production of reactive oxygen species (ROS) in plant tissues, such as hydrogen peroxide $\left(\mathrm{H}_{2} \mathrm{O}_{2}\right)$, superoxide $\left(\mathrm{O}_{2}^{-}\right)$, singlet oxygen $\left({ }^{1} \mathrm{O}_{2}\right)$, hydroxyl radicals $(\mathrm{OH})$, and alkoxy radicals (RO). Salinity-induced ROS provoke oxidative damages at the cellular level by increasing lipid peroxidation, protein degradation, and decreasing membrane stability [14-17].

In response to salt stress, plants have evolved various adaptive mechanisms to withstand that stress including the accumulation of osmoprotectants and anti-oxidative compounds [4]. Supporting plant defense system by exogenous application of adjuvants, such as selenium $\left(\mathrm{Se}^{2-}\right)$, contributes to the alleviation of the adverse effects of salt stress; regulates several processes for increasing plant tolerance and protects cellular and subcellular tissues from the cytotoxic effects of ROS [18,19].

Egypt belongs to Se-deficient areas, where the daily intake is less than $55 \mu \mathrm{g}$ per day [20]. Se is counted as important microelements for plants, having a beneficial role for enhancing growth and development, due to its physiological and anti-oxidative properties [21,22]. However, requirement of Se depends on plant species and also different concentrations [23]. At low concentration, Se stimulates the antioxidant machinery and protects plant tissues from oxidative stress, but at high concentration, it behaves like heavy metals and acts as a pro-oxidant [23]. Selenium application intensifies the phloem transport through phloem and xylem [22]. Se is involved in the structural construction of some selenoproteins, which has an important role in scavenging ROS [20].

Previous literature indicated that exogenous Se prompts abiotic stress tolerance including salinity [24-26]. Se has markedly alleviated salinity stress in maize plants via the improvements of photosynthetic capacity and the antioxidant defense system by increasing the activities of superoxide dismutase (SOD) and ascorbate peroxidase (APX) enzymes [27]. Maintaining cell turgor and membrane integrity and increasing fruit yield of droughtstressed tomato plants were achieved by exogenous Se application, either to soil or by foliar spraying [19]. Exogenous Se spray could regenerate membrane enzymes and reactivate the important metabolites transport for chloroplast [28]. Recently, some other evidence has shown that lower concentrations of selenium might protect plants against abiotic stresses. According to [26], Se stimulated photosynthetic capacity and biomass accumulation of cadmium-stressed Oryza sativa. Spraying Se at $20 \mathrm{mg} \mathrm{L}^{-1}$ helped in maintaining homeostasis between $\mathrm{Na}^{+}$and $\mathrm{K}^{+}$, as it led to an increase of $\mathrm{K}^{+}$and decline of $\mathrm{Na}^{+}$in leaves and roots of Zea mays plants grown under $12 \mathrm{dS} \mathrm{m}^{-1}$ soil salinity [29].

To the best of our knowledge, very limited information is available on the effect of Se at a field study and its prospective role in ameliorating salinity stress in widely cultivated and consumed crops like onion. In our endeavor to investigate the potential effect of Se foliar application in alleviating salt-induced damages on onion, we hypothesized that Se might induce a higher concentration of osmoprotectants and improve growth and productivity of salt-stressed onion, highlighting Se effects on, photosynthetic efficiency, stomatal conductance, plant water status, bulb yield, and the activities of enzymatic and non-enzymatic antioxidants. 


\section{Materials and Methods}

\subsection{Experimental Layout and Growth Condition}

In the experimental station of the Faculty of Agriculture, Fayoum University $\left(29.2938^{\circ}\right.$ $\mathrm{N} ; 30.9144^{\circ} \mathrm{E}$ ), southeast Fayoum, Egypt, field trials were conducted during two seasons of 2016/17 (SI) and 2017/18 (SII). Following the climatic characterization, the climate in this region is hyper-arid as reported by [30]. Healthy seeds of the most widely cultivated onion cultivar (Giza 20) in Egypt were sown on 28 September 2016 and 2017. Seedlings were then transplanted to the open field on 8 December of both 2016 and 2017, in four rows of $0.10 \mathrm{~m}$ apart per bed ( $1.1 \mathrm{~m}$ wide), with a distance of $0.15 \mathrm{~m}$ between plants. All plants were fertilized with $150 \mathrm{~kg} \mathrm{~N} \mathrm{ha}^{-1}, 62 \mathrm{~kg} \mathrm{P}_{2} \mathrm{O}_{5} \mathrm{ha}^{-1}$, and $72 \mathrm{~kg} \mathrm{~K}_{2} \mathrm{O}$ ha ${ }^{-1}$. Furthermore, all the cultural procedures and pest management were performed following the recommendation of the Ministry of Agriculture and Land Reclamation in Egypt.

The daily reference evapotranspiration (ETo) was computed according to FAO penman Monteith method [31], using meteorological data recorded near the experimental site. The irrigation was applied by surface irrigation at 15 days intervals equally to all onion plants. The required water was supplied via plastic pipe ( $50 \mathrm{~mm}$ diameter) for each plot and the irrigation water transferred to each plot was controlled using the following equation [32]:

$$
\mathrm{Q}=\mathrm{CA} \sqrt{2 \mathrm{gh}} \times 10^{-3}
$$

where $\mathrm{Q}$ is the discharge of irrigation water $\left(\mathrm{L} \mathrm{s}^{-1}\right), \mathrm{C}$ is the coefficient of discharge $(=0.62)$, A is the cross-section area of irrigation pipe $\left(=19.62 \mathrm{~cm}^{2}\right), \mathrm{g}$ is the gravity acceleration, $\left(=986 \mathrm{~cm} \mathrm{~s}^{-2}\right)$, and $\mathrm{h}$ is the average effective head of water $(\mathrm{cm})$.

\subsection{Soil Analyses, Treatments, and Experimental Design}

A representative soil sample was collected from 10 soil profiles from the experimental site to determine the soil's physical and chemical properties. Table 1 presents the physical and chemical soil analysis, which was quantified as depicted by $[33,34]$. In the study area, the soil is coarse in texture (Sandy loam), moderately deep-classified as Typic Torripsamments-siliceous, and hyperthermic, according to the USDA soil taxonomy [35]. The soil analyses indicated that the ECe value is $5.27 \mathrm{dS} \mathrm{m}^{-1}$, which was rated as moderate saline soil [36]. In a parcel site with similar characteristics, Se concentrations $\left(\mathrm{mg} \mathrm{kg}^{-1}\right)$ was monitored, as illustrated in Table $2.5 \mathrm{~mL}$ of $\mathrm{HNO} 3$ were added to $0.5 \mathrm{~g}$ of sample in a $250 \mathrm{~mL}$ dry flask and stirred. Thus, all the material was wet. Then, $4 \mathrm{~mL}$ of $33 \% \mathrm{H}_{2} \mathrm{O}_{2}$ were added in a well-ventilated hood and slightly stirred after the addition. It was heated on a hot plate and a strong effervescence was produced. When the brown fumes were less dense (7-8 $\mathrm{min})$, the solution was allowed to cool. A slightly yellow dissolution and a small white solid quantity in suspension still remained. The solution was filtered, washed with $5 \mathrm{~mL}$ of (1:1) $\mathrm{HCI}$ (density $1.18 \mathrm{~g} \mathrm{~mL}^{-1}$ ), and diluted up to $25 \mathrm{~mL}$ with distilled $\mathrm{H}_{2} \mathrm{O}$. The readings of digested samples were performed using an Induction Plasma Spectrometer (ICP), Thermo Jarell Ash brand, IRIS Advantage model, following the 984.27 [37]. The quantification of Se $\left(\mathrm{mg} \mathrm{kg}^{-1} \mathrm{DW}\right)$ was performed.

Table 1. Some initial physical and chemical properties of the experimental soil.

\begin{tabular}{|c|c|c|c|c|c|c|c|c|c|}
\hline \multicolumn{10}{|c|}{ Physical Properties } \\
\hline \multicolumn{4}{|c|}{ Particle Size Distribution } & & \multirow{2}{*}{\multicolumn{2}{|c|}{ Bulk Density $\left(\mathrm{Mg} \mathrm{m}^{-3}\right)$}} & \multirow{2}{*}{ FC (\%) } & \multirow{2}{*}{ WP (\%) } & \multirow{2}{*}{$\mathrm{AW}(\%)$} \\
\hline Sand (\%) & Silt (\%) & Clay $(\%)$ & Texture Class & & & & & & \\
\hline 71.6 & 12.9 & 15.5 & Sandy loam & & 1.52 & & 21 & 9.7 & 11.3 \\
\hline \multicolumn{10}{|c|}{ Chemical properties } \\
\hline \multirow{2}{*}{$\begin{array}{c}\text { ECe (dS } \\
\left.m^{-1}\right)\end{array}$} & \multirow{2}{*}{$\mathrm{pH}$} & \multirow{2}{*}{$\mathrm{CaCO}_{3}(\%)$} & \multirow{2}{*}{$O C *(\%)$} & \multirow{2}{*}{ Total N (mg kg $\left.{ }^{-1}\right)$} & \multicolumn{5}{|c|}{ Available Nutrients $\left(\mathrm{mg} \mathrm{kg}^{-1}\right)$} \\
\hline & & & & & $\mathrm{P}$ & K & $\mathrm{Fe}$ & $\mathrm{Mn}$ & $\mathrm{Zn}$ \\
\hline 5.27 & 7.84 & 8.30 & 1.1 & 13.91 & 3.59 & 43.66 & 3.88 & 1.35 & 0.92 \\
\hline
\end{tabular}

FC: field capacity, WP: wilting point, AW: available water, and * OC: organic content. 
Table 2. Selenium concentrations $\left(\mathrm{mg} \mathrm{kg}^{-1}\right)$ monitoring in the studied area.

\begin{tabular}{ccccccc}
\hline \multirow{2}{*}{ Soil Depth $(\mathbf{c m})$} & \multicolumn{2}{c}{ Before Planting } & \multicolumn{2}{c}{ After 90 Days } & \multicolumn{2}{c}{ After 120 Days } \\
\cline { 2 - 7 } & Total & Available & Total & Available & Total & Available \\
\hline $0-20$ & 1.06 & 0.43 & 1.07 & 0.45 & 1.07 & 0.48 \\
$20-40$ & 0.88 & 0.29 & 0.92 & 0.39 & 0.83 & 0.37 \\
$40-60$ & 0.62 & 0.19 & 0.76 & 0.22 & 0.69 & 0.30 \\
Average & 0.85 & 0.30 & 0.92 & 0.35 & 0.86 & 0.38 \\
\hline
\end{tabular}

Se $\left(\mathrm{Na}_{2} \mathrm{SeO}_{4}\right.$; Sigma-Aldrich, St. Louis, $\mathrm{MO}$, USA) was foliarly-applied to onion plants grown under $5.27 \mathrm{dS} \mathrm{m}^{-1}$ soil salinity with three concentrations: $0 \mathrm{mg} \mathrm{L}^{-1}$ (spraying tap water $+0.1 \%, v / v$ Tween-20 as a control), $25 \mathrm{mg} \mathrm{L}^{-1}$, and $50 \mathrm{mg} \mathrm{L}^{-1}$. Spraying Se was started from 20 days after transplanting at three times with 20 days intervals. Spraying was carried out using hand atomizer to run off. Tween-20 $(0.1 \%, v / v)$ was added to the sprays with the Se solution as a surfactant to facilitate penetration of the solution into the leaf tissues.

The experimental layout was a randomized complete block design with three replications. The total experimental area was $275 \mathrm{~m}^{-2}$, included 9 plots; each one was approximately $16.5 \mathrm{~m}^{-2}$ ( $1.1 \mathrm{~m}$ wide $\times 15 \mathrm{~m}$ length). Each experimental plot contained 12 planting rows set $10 \mathrm{~cm}$ apart, and $15 \mathrm{~cm}$ was a distance between plants to achieve the typical practice of onion producers. Treatments were randomly distributed within each block (Replica). Each of the three replicates contains all treatments. From each experimental unit (plot) three plants were collected for the analysis $(n=9)$ for growth measurements, and $n=$ 5 for physiological measurements.

\subsection{Onion Growth, Biomass, and Bulb Yield}

At 91 days after transplanting, three plants per plot were chosen randomly to determine shoot length and number of leaves. Thereafter, leaf area was measured using a graph sheet and counting, as described by [4]. Shoot dry weight plant ${ }^{-1}$ was recorded after oven-drying at $70^{\circ} \mathrm{C}$ until a constant weight.

At 8 may of both 2017 and 2018 all plants of each plot area were harvested then total bulb yield was determined, which was sorted to three bulb sizes; $<50 \mathrm{~mm}, 50-75 \mathrm{~mm}$, and $>75 \mathrm{~mm}$. Water use efficiency (WUE; $\mathrm{kg} \mathrm{m}^{-3}$ ) was calculated as a ratio of total bulb yield to irrigation water applied [38], according to the following formula:

$$
\text { WUE }=\frac{\text { Bulb yield }\left(\mathrm{kg} \mathrm{ha}^{-1}\right)}{\text { Water applied }\left(\mathrm{m}^{3} \mathrm{ha}^{-1}\right)}
$$

\subsection{Photosynthetic Efficiency, Plant Water Status, and Stomatal Conductance (Gs)}

Fully developed leaves were collected in two different sunny days to measure relative chlorophyll content (SPAD value; $n=5$ ), using a chlorophyll meter (SPAD-502, Minolta, Japan). Afterwards, chlorophyll $a$ fluorescence was measured using a portable fluorometer $(n=5)$ (Handy PEA, Hansatech Instruments Ltd., Kings Lynn, UK). Chlorophyll fluorescence parameters in terms of the maximum quantum yield PSII $\left(F_{v} / F_{m}\right)$ was calculated considering the equation outlined by [39], the activity of PSII reaction centers $\left(F_{v} / F_{0}\right)$ was calculated [40] and the photosynthetic performance index (PI) was quantified [41]. Leaf membrane stability index (MSI), using the methodology of [42], modified by [43], and leaf relative water content (RWC), using the method of [44], modified by [45] were then conducted. $2 \mathrm{~cm}$ diameter discs (10 discs) from the fully-expanded leaf were weighed (fresh mass; FM) and immediately floated on distilled water in Petri dishes for $6 \mathrm{~h}$, in a dark room, the turgid mass (TM) was then measured. Discs dry mass (DM) was recorded after 
dehydration at $70{ }^{\circ} \mathrm{C}$ until the constant weight. The RWC was then calculated according to the following formula:

$$
\operatorname{RWC}(\%)=[(\mathrm{FM}-\mathrm{DM}) /(\mathrm{TM}-\mathrm{DM})] \times 100
$$

On the other hand, $0.2 \mathrm{~g}$ Leaf sample was placed in a test-tube containing $10 \mathrm{~mL}$ of distilled water. Tubes were then heated at $40{ }^{\circ} \mathrm{C}$ in a water bath for half an hour, and the electrical conductivity (C1) of the solution was recorded, using a conductivity bridge. A second sample was boiled at $100{ }^{\circ} \mathrm{C}$ for $10 \mathrm{~min}$, and the conductivity was measured (C2). The MSI was calculated using the formula:

$$
\operatorname{MSI}(\%)=[1-(\mathrm{C} 1 / \mathrm{C} 2)] \times 100
$$

35 days after transplanting, stomatal conductance (Gs) $\left(\mathrm{mmol}^{-2} \mathrm{~S}^{-1}\right)$ was measured $(n=5)$ in field using leaf porometer (Decagon Devices Inc., Pullman, WA, USA) (from 9:00 a.m. to 12:00 p.m.).

\subsection{Osmoprotectants and Selenium (Se) Contents Determinations}

Osmoprotectants content i.e., total soluble sugar, free proline, choline, and glycine betaine were assessed in onion leaves and bulbs. Leaf surface was thoroughly washed in running tap water, followed by washing with double distilled water. Thereafter, dried samples of $0.5 \mathrm{~g}$ were used to determine free proline $\left(\mathrm{mg} \mathrm{g}^{-1} \mathrm{DW}\right)$, following the method described by [46]. Acid ninhydrin reagent was prepared by warming $1.25 \mathrm{~g}$ ninhydrin in $30 \mathrm{~mL}$ glacial acetic acid and $20 \mathrm{~mL} 6 \mathrm{M}$ phosphoric acid with agitation until complete solubility; kept cool and stored at $4{ }^{\circ} \mathrm{C}$ for $24 \mathrm{~h}$ until the reagent remains stable. Two $\mathrm{ml}$ of the filtrate were mixed with $2 \mathrm{~mL}$ of glacial acetic acid and $2 \mathrm{~mL}$ of the acid ninhydrin reagent in a test tube. At the same time heat the samples at $100{ }^{\circ} \mathrm{C}$ for $60 \mathrm{~min}$, with caps in place. The reaction mixture was extracted with $4 \mathrm{~mL}$ toluene, mixed vigorously in a test tube for 15-20 s. The chromophore containing toluene was aspired from the aqueous phase and warmed to room temperature. The absorbance measured at $520 \mathrm{~nm}$ using toluene as blank. The concentration of proline in the extract samples was calculated using the calibration curve was calculated on a dry matter basis. For the determination of total soluble sugars content ( $\left.\mathrm{mg} \mathrm{g}^{-1} \mathrm{DW}\right), 0.2 \mathrm{~g}$ dried samples were used, as outlined by [47]. $0.2 \mathrm{~g}$ dried leaf sample was homogenized in $5 \mathrm{~mL}$ of $96 \%(v / v)$ ethanol, and then washed with $5 \mathrm{~mL} \mathrm{70 \%}(v / v)$ ethanol. The extract was centrifuged at $3500 \times g$ for $10 \mathrm{~min}$, and the supernatant was stored at $4{ }^{\circ} \mathrm{C}$ prior to determination. The reaction mixture of $0.1 \mathrm{~mL}$ of the ethanolic extract and $3 \mathrm{~mL}$ of freshly-prepared anthrone reagent $(150 \mathrm{mg}$ anthrone plus $100 \mathrm{~mL}$ of $72 \%(v / v)$ sulphuric acid) was placed in a boiling water bath for $10 \mathrm{~min}$, and was then cooled. The absorbance of the mixture was recorded at $625 \mathrm{~nm}$. Leaf and bulb content of glycine betaine $\left(\mathrm{mmol} \mathrm{g}^{-1} \mathrm{DW}\right)$ and choline $\left(\mathrm{mmol} \mathrm{g}^{-1} \mathrm{DW}\right)$ were determined based on the analytical procedures depicted by [48] and [49], respectively, using Shimadzu-V

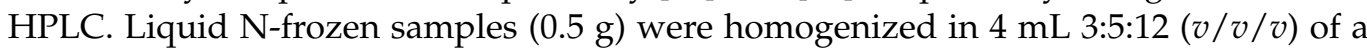
water, chloroform, methanol mixture, and were then incubated at $4{ }^{\circ} \mathrm{C}$ over- night. Using BioRad AG1-X8 ion exchange resin, purification of upper methanolic phase $(1 \mathrm{~mL})$ taken from the extract was done. Thereafter, centrifugation $(5000 \times g$ for $10 \mathrm{~min})$ was applied to remove the ion exchange resin, and supernatant was then filtered through a $0.45 \mathrm{~mL}$ membrane filter before loading to the HPLC system. With using nu-cleogel RP column (RP-S 100-8, $300 \times 7.7 \mathrm{~mm})$ proceeded by a guard column, mobile phase $\left(15 \mathrm{mM} \mathrm{KH}_{2} \mathrm{PO}_{4}\right)$ was delivered by an analytical isocratic pump at a flow rate of $0.8 \mathrm{~mL} \mathrm{~min}{ }^{-1}$ at $70{ }^{\circ} \mathrm{C}$. Sample contents of choline and GB were detected by UV detector at $230 \mathrm{~nm}$, and were then quantified by comparing the peak surface areas (2.5 min and $3.5 \mathrm{~min}$ ) with those obtained with pure choline and GB standards, respectively. Se content ( $\left.\mathrm{mg} \mathrm{g}^{-1} \mathrm{DW}\right)$ quantification in both onion leaves and bulbs was conducted using the analytical procedures of ICP-MS [50]. 


\subsection{Assays of Antioxidants Activities: Non-Enzymatic and Enzymatic}

In both leaves and bulbs, ascorbic acid (AsA) and reduced glutathione (GSH) were determined according to the methods of [51] and [52], respectively, and both expressed as $\mathrm{mmol} \mathrm{g}{ }^{-1}$ fresh weight. For AsA contents determination, extraction was performed in $10 \mathrm{~mL}$ of $6 \%(w / v)$ trichloroacetic acid, and the extract was then mixed with $2 \%(w / v)$ dinitrophenylhydrazine, then one drop of $10 \%(w / v)$ thiourea in $70 \%(v / v)$ ethanol was added. After boiling the mixture for $15 \mathrm{~min}$ and cooling, $5 \mathrm{~mL}$ of $80 \%(v / v) \mathrm{H}_{2} \mathrm{SO}_{4}$ was added and absorbances were read at $530 \mathrm{~nm}$ to calculate the contents of AsA from a standard curve. For GSH contents determination, homogenization of fresh leaf tissue $(50 \mathrm{mg}$ ) was exercised in $2 \mathrm{~mL}$ of $2 \%(v / v)$ metaphosphoric acid, and centrifugation was then applied at $17,000 \times \mathrm{g}$ for $10 \mathrm{~min}$. Neutralization of supernatant $(0.9 \mathrm{~mL})$ was done with $0.6 \mathrm{~mL}$ of $10 \%(w / v)$ sodium citrate. Assessments of 3 replicates were made for each sample. A composition of $700 \mu \mathrm{L}$ of $0.3 \mathrm{mM}$ NADPH, $100 \mu \mathrm{L}$ of $6 \mathrm{mM}$ 5,5'-dithio-bis-2nitrobenzoicacid, $100 \mu \mathrm{L}$ distilled water, and $100 \mu \mathrm{L}$ of extract was of each assay $(1.0 \mathrm{~mL})$ that was stabilized at $25^{\circ} \mathrm{C}$ for 3-4 min, and GSH reductase $\left(10 \mu \mathrm{L}\right.$ of 50 Units $\left.\mathrm{mL}^{-1}\right)$ was then added and absorbances were read at $412 \mathrm{~nm}$ to calculate GSH contents from a standard curve.

For SOD, CAT, GR, and APX extraction, samples ( $0.5 \mathrm{~g}$ fresh sample) were homogenized in ice cold $0.1 \mathrm{M}$ phosphate buffer $(\mathrm{pH}=7.5$ ) containing $0.5 \mathrm{mM}$ EDTA with pre-chilled pestle and mortar. Each homogenate was transferred to centrifuge tubes and was centrifuged at $4{ }^{\circ} \mathrm{C}$ in Beckman refrigerated centrifuge for $15 \mathrm{~min}$ at $15,000 \times \mathrm{g}$. The supernatant was used for enzyme activity assay [53]. The enzymes activities determinations were performed, and all expressed as $\mu \mathrm{mol} \mathrm{mg}{ }^{-1}$ protein. The activity of superoxide dismutase (SOD; EC 1.15.1.1) was assessed from recording an inhibition of cytochrome reduction of nitroblue tetrazolium (NBT) at $540 \mathrm{~nm}$ [54]. About $3 \mathrm{~mL}$ of reaction mixture, containing $0.1 \mathrm{~mL}$ of $200 \mathrm{mM}$ methionine, $0.1 \mathrm{~mL}$ of $2.25 \mathrm{mM}$ nitro-blue tetrazolium (NBT), $0.1 \mathrm{~mL}$ of $3 \mathrm{mM}$ EDTA, $1.5 \mathrm{~mL}$ of $100 \mathrm{mM}$ potassium phosphate buffer, $1 \mathrm{~mL}$ distilled water, and $0.05 \mathrm{~mL}$ of enzyme extraction, were taken in test tubes in duplicate from each enzyme sample. Two tubes without enzyme extract were taken as control. The reaction was started by adding $0.1 \mathrm{~mL}$ riboflavin $(60 \mu \mathrm{M})$ and placing the tubes below a light source of two florescent lamps $(15 \mathrm{~W})$ for $15 \mathrm{~min}$. Reaction was stopped by switching off the light and covering the tubes with black cloth. Tubes without enzyme developed maximal color. A non-irradiated complete reaction mixture, which did not develop color, served as blank. Absorbance was recorded at $560 \mathrm{~nm}$ and one unit of enzyme activity was taken as the quantity of enzyme, which reduced the absorbance reading of samples to 50\% in comparison with tubes lacking enzymes. Catalase (CAT; EC 1.11.1.6) activity was performed by measuring the decomposition rate of $\mathrm{H}_{2} \mathrm{O}_{2}$ at $240 \mathrm{~nm}$ [55]. About $3 \mathrm{~mL}$ reaction mixture containing $1.5 \mathrm{~mL}$ of $100 \mathrm{mM}$ potassium phosphate buffer $(\mathrm{pH}=7), 0.5 \mathrm{~mL}$ of $75 \mathrm{mM}$ $\mathrm{H}_{2} \mathrm{O}_{2}, 0.05 \mathrm{~mL}$ enzyme extraction, and distilled water to make up the volume to $3 \mathrm{~mL}$. Reaction started by adding $\mathrm{H}_{2} \mathrm{O}_{2}$ and decrease in absorbance recorded at $240 \mathrm{~nm}$ for $1 \mathrm{~min}$. Enzyme activity was computed by calculating the amount of $\mathrm{H}_{2} \mathrm{O}_{2}$ decomposed. Ascorbate peroxidase (APX; EC 1.11.1.11) activity was measured, according to [56] by monitoring the rate of ascorbate oxidation at $290 \mathrm{~nm}\left(\mathrm{E}=2.8 \mathrm{mM}^{-1} \mathrm{~cm}^{-1}\right)$. The reaction mixture contained $25 \mathrm{mM}$ phosphate buffer ( $\mathrm{pH}=7), 0.1 \mathrm{mM}$ EDTA, $1 \mathrm{mM} \mathrm{H}_{2} \mathrm{O}_{2}, 0.25 \mathrm{mM}$ AsA, and the enzyme sample. No change in absorption found in the absence of AsA in the test medium. Glutathione reductase (GR; EC 1.6.4.1) activity was determined by measuring the oxidation of NADPH at $340 \mathrm{~nm}$ [56]. Glutathione reductase (GR; EC 1.6.4.1) activity was assayed by recording the increase in absorbance in the presence of oxidized glutathione (GSSG) and 5,5-dithiobis-2-nitrbenzoic acid (DTNB) [56]. The reaction mixture contained $1 \mathrm{~mL}$ of $0.2 \mathrm{M}$ potassium phosphate buffer $(\mathrm{pH}=7.5)$ containing $0.1 \mathrm{mM}$ EDTA, $0.5 \mathrm{~mL}$ of $3 \mathrm{mM}$ DTNB in $0.01 \mathrm{M}$ potassium phosphate buffer $(\mathrm{pH}=7.5), 0.1 \mathrm{~mL}$ of $2 \mathrm{mM} \mathrm{NADPH}, 0.1 \mathrm{~mL}$ enzyme extract, and distilled water to make up a final volume of $2.9 \mathrm{~mL}$. Reaction initiated by adding $0.1 \mathrm{~mL}$ of $2 \mathrm{mM}$ GSSG. The increase in absorbance at $412 \mathrm{~nm}$ recorded at $25^{\circ} \mathrm{C}$ over a period of $5 \mathrm{~min}$ on a spectrophotometer. 


\subsection{Statistical Analysis}

Data of both field experimental seasons were analyzed using Genstat statistical software (version 11; VSN International Ltd., Oxford, UK). Differences between the treatment's means were separated by Student Newman Keuls test at $p \leq 0.05$. The results are presented as means \pm standard error.

\section{Results}

\subsection{Onion Growth and Biomass under Selenium and Salinity Stress}

Onion growth characteristics and biomass results are presented in Table 3. Se-treated onions with $25 \mathrm{mg} \mathrm{L}^{-1}$ or $50 \mathrm{mg} \mathrm{L}^{-1}$ showed enhanced growth (e.g., shoot length, number of leaves, and leaf area) and biomass (shoot fresh and dry weight) compared to the nontreated plants. These improvements were more pronounced at $50 \mathrm{mg} \mathrm{L}^{-1} \mathrm{Se}$, which caused an increase of shoot length by $20 \%$ and $39 \%$, the number of leaves by $45 \%$ and $30 \%$, leaf area by $134 \%$ and $184 \%$, shoot fresh weight by $165 \%$ and $134 \%$, and shoot dry weight by $183 \%$ and $131 \%$ in SI and SII, respectively, compared to the control.

Table 3. Effects of foliar applications with Selenium (Se) on vegetative growth characteristics of onion under saline soil $\left(\mathrm{EC}=5.2 \mathrm{dS} \mathrm{m}^{-1}\right)$ condition in 2016/17 (SI) and 2017/18 (SII) seasons.

\begin{tabular}{|c|c|c|c|c|c|}
\hline Se Treatment & Shoot Length (cm) & Number of Leaves Plant ${ }^{-1}$ & $\begin{array}{c}\text { Leaf Area } \\
\left(\mathrm{dm}^{-2}\right)\end{array}$ & Shoot FW (g) & Shoot DW (g) \\
\hline \multicolumn{6}{|c|}{ SI } \\
\hline Selenium (Se) & ** & * & $* *$ & $* *$ & ** \\
\hline $0 \mathrm{mg} \mathrm{L}^{-1}$ & $76.0 \pm 1.7^{\mathrm{b}, \#}$ & $7.7 \pm 0.3^{c}$ & $8.0 \pm 0.9^{c}$ & $78.9 \pm 8.2^{\mathrm{c}}$ & $8.2 \pm 0.8^{c}$ \\
\hline $25 \mathrm{mg} \mathrm{L}^{-1}$ & $85.5 \pm 3.1^{\mathrm{a}}$ & $9.5 \pm 0.4^{b}$ & $13.3 \pm 0.9^{b}$ & $144.8 \pm 9.0^{b}$ & $17.4 \pm 1.8^{b}$ \\
\hline $50 \mathrm{mg} \mathrm{L}^{-1}$ & $91.0 \pm 1.3^{\mathrm{a}}$ & $11.2 \pm 0.6^{\mathrm{a}}$ & $18.7 \pm 1.2^{\mathrm{a}}$ & $209.2 \pm 8.7^{\mathrm{a}}$ & $23.2 \pm 1.3^{\mathrm{a}}$ \\
\hline \multicolumn{6}{|c|}{ SII } \\
\hline Selenium (Se) & $* *$ & $* *$ & $* *$ & $* *$ & $* *$ \\
\hline $0 \mathrm{mg} \mathrm{L}^{-1}$ & $67.0 \pm 4.4^{b}$ & $7.7 \pm 0.5^{b}$ & $6.9 \pm 1.2^{b}$ & $84.5 \pm 7.8^{b}$ & $8.9 \pm 1.1^{b}$ \\
\hline $25 \mathrm{mg} \mathrm{L}^{-1}$ & $90.0 \pm 1.0^{\mathrm{a}}$ & $9.8 \pm 0.5^{\mathrm{a}}$ & $19.5 \pm 0.1^{\mathrm{a}}$ & $192.3 \pm 16.4^{\mathrm{a}}$ & $20.5 \pm 2.1^{a}$ \\
\hline $50 \mathrm{mg} \mathrm{L}^{-1}$ & $93.3 \pm 1.3^{\mathrm{a}}$ & $10.0 \pm 0.2^{\mathrm{a}}$ & $19.6 \pm 0.7^{\mathrm{a}}$ & $197.6 \pm 0.1^{\mathrm{a}}$ & $20.6 \pm 0.2^{\mathrm{a}}$ \\
\hline
\end{tabular}

\# Values are means of $(n=9)$. Mean values in each column followed by a different lower case letter are significantly different by Student Newman-Keuls test at $p \leq 0.05 .{ }^{* *}$ and ${ }^{*}$ indicate respective differences at $p \leq 0.05$ and $p \leq 0.01$ probability level.

\subsection{Plant Water Status, Water Use Efficiency (WUE), Stomatal Conductance (Gs), and Photosynthetic Efficiency, in Response to Selenium under Salinity Stress}

As presented in Table 4, in both seasons, salt-stressed onion plants sprayed with $25 \mathrm{mg} \mathrm{L}^{-1}$ or $50 \mathrm{mg} \mathrm{L}^{-1}$ Se markedly increased MSI by $9 \%$ and RWC by $19 \%$ (on average of SI and SII), compared to those unsprayed plants, which recorded the lowest values. Results exhibited that, $50 \mathrm{mg} \mathrm{L}^{-1}$ Se-treated plants showed enhanced WUE by $79 \%$, relative to the control (Table 4). Application of Se $\left(25 \mathrm{mg} \mathrm{L}^{-1}\right.$ or $\left.50 \mathrm{mg} \mathrm{L}^{-1}\right)$ significantly increased relative chlorophyll content (SPAD value) and chlorophyll fluorescence apparatus as $F_{v} / F_{m}$, $F_{v} / F_{0}$ and PI in comparison of the control (Figures 1 and 2). Under saline soil condition, $50 \mathrm{mg} \mathrm{L}^{-1}$ Se-treated plants showed higher stomatal conductance (Gs) by $61 \%$ compared to the control and was more effective than $25 \mathrm{mg} \mathrm{L}^{-1}$ Se (Figure 2).

\subsection{Bulb Yields and Water Use Efficiency under Selenium and Salinity Stress}

Salinity noticeably decreased total bulb yield as well as large bulb grades $(50-75 \mathrm{~mm}$ and $>75 \mathrm{~mm}$ ) yield, however, it increased the yield of small bulbs $(<50 \mathrm{~mm})$ (Table 5). Large bulb yield progressively increased with increasing Se level from $25 \mathrm{mg} \mathrm{L}^{-1}$ to $50 \mathrm{mg} \mathrm{L}^{-1}$. This increase in total bulb yield as a result of Se application, synchronized with increasing WUE. Results exhibited that, $50 \mathrm{mg} \mathrm{L}^{-1}$ Se-treated plants showed enhanced productivity of different bulb sizes ( $50-75 \mathrm{~mm}$ and $>75 \mathrm{~mm}$ ), and total bulb yield by $96 \%, 128 \%$, and $78 \%$, respectively, relative to the control (Table 5). 
Table 4. Effects of foliar applications with Selenium (Se) on RWC\%, MSI\% and water use efficiency (WUE) of onion plants under saline soil $\left(E C=5.2 \mathrm{dS} \mathrm{m}^{-1}\right)$ condition in 2016/17 (SI) and 2017/18 (SII) seasons.

\begin{tabular}{|c|c|c|c|}
\hline Se Treatment & RWC\% & MSI\% & WUE $\left(\mathrm{kg} \mathrm{m}^{-3}\right)$ \\
\hline \multicolumn{4}{|c|}{ SI } \\
\hline Selenium (Se) & * & * & $* *$ \\
\hline $0 \mathrm{mg} \mathrm{L}^{-1}$ & $82.2 \pm 0.8^{b, \#}$ & $46.4 \pm 0.7^{b}$ & $3.5 \pm 0.3^{b}$ \\
\hline $25 \mathrm{mg} \mathrm{L}^{-1}$ & $88.7 \pm 1.9^{\mathrm{a}}$ & $53.3 \pm 2.7^{\mathrm{a}}$ & $5.0 \pm 0.4^{\mathrm{a}}$ \\
\hline $50 \mathrm{mg} \mathrm{L}^{-1}$ & $91.3 \pm 0.9^{a}$ & $54.6 \pm 1.7^{\mathrm{a}}$ & $6.2 \pm 0.1^{\mathrm{a}}$ \\
\hline \multicolumn{4}{|c|}{ SII } \\
\hline Selenium (Se) & $* *$ & * & $* *$ \\
\hline $0 \mathrm{mg} \mathrm{L}^{-1}$ & $84.2 \pm 0.5^{c}$ & $44.2 \pm 62^{b}$ & $3.5 \pm 0.2^{\mathrm{c}}$ \\
\hline $25 \mathrm{mg} \mathrm{L}^{-1}$ & $91.9 \pm 0.1^{\mathrm{a}}$ & $54.2 \pm 0.5^{\mathrm{a}}$ & $5.5 \pm 0.3^{b}$ \\
\hline $50 \mathrm{mg} \mathrm{L}^{-1}$ & $89.8 \pm 0.3^{b}$ & $52.6 \pm 0.5^{a}$ & $6.3 \pm 0.2^{\mathrm{a}}$ \\
\hline
\end{tabular}

\footnotetext{
\# Values are means of $(n=5)$. Mean values in each column followed by a different lower case letter are significantly different by Student Newman-Keuls test at $p \leq 0.05 .{ }^{* *}$ and ${ }^{*}$ indicate respective differences at $p \leq 0.05$ and $p \leq 0.01$ probability level.
}

SI
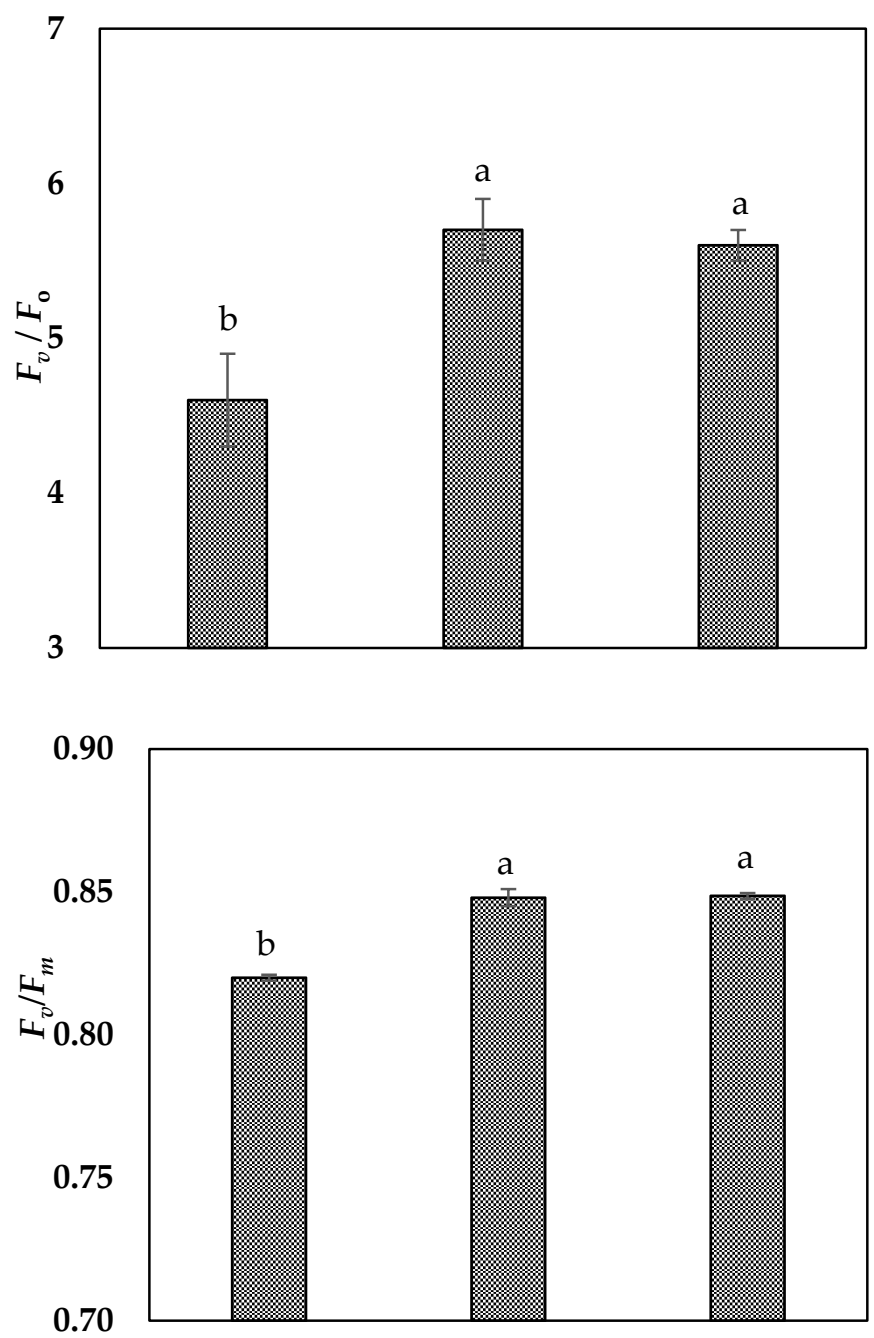

SII
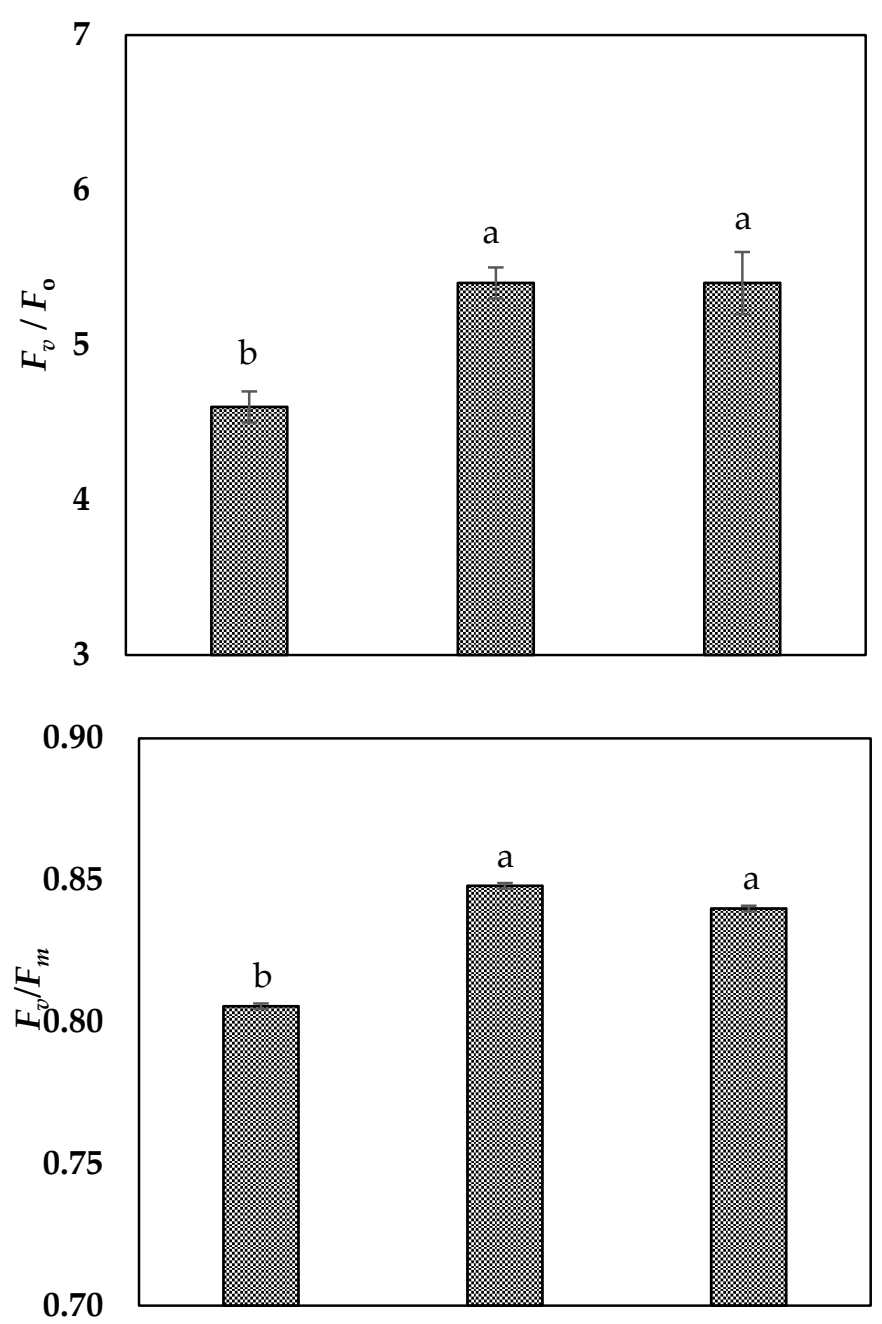

Figure 1. Cont. 

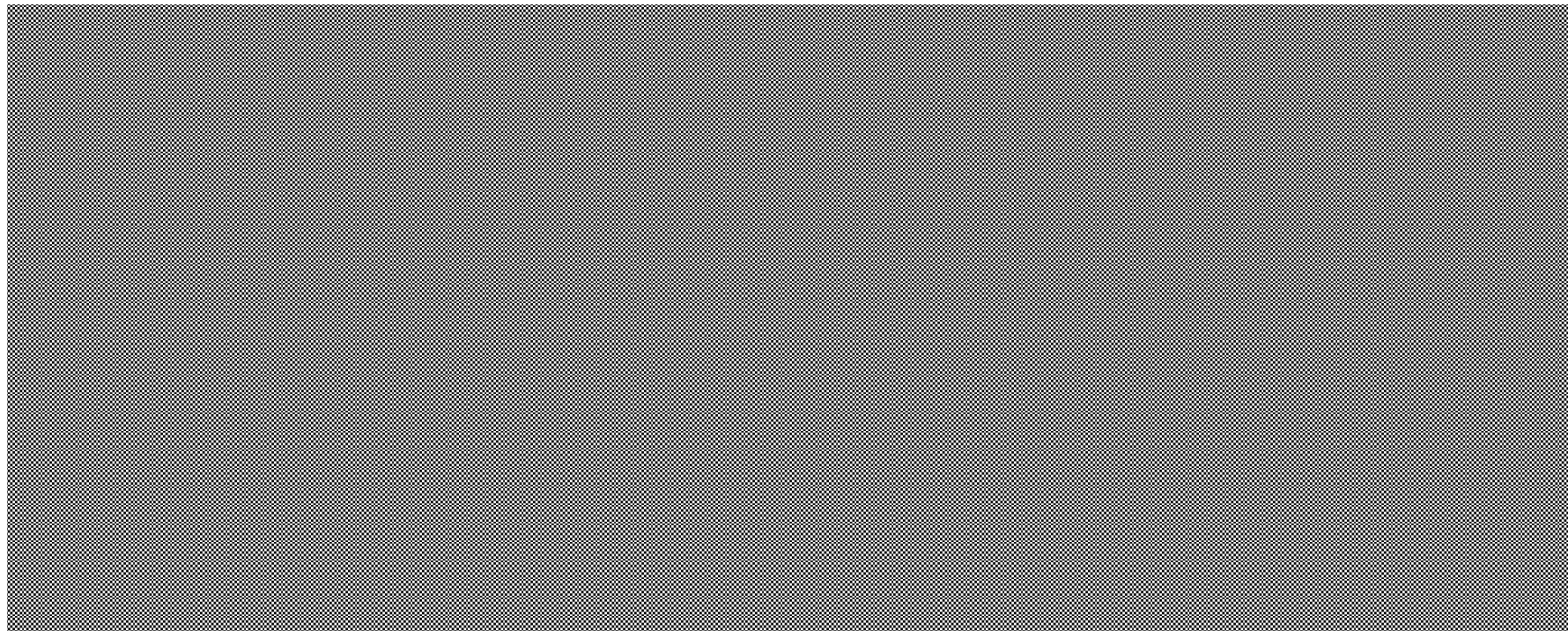

Figure 1. Effects of selenium (Se; $\left.\mathrm{mg} \mathrm{L}^{-1}\right)$ foliar applications on Chlorophyll a fluorescence i.e., $\left(F_{v} / F_{m}\right.$ and $\left.F_{v} / F_{0}\right)$ and photosynthetic performance index $(\mathrm{PI})$ of onion under saline soil $\left(\mathrm{EC}=5.2 \mathrm{dS} \mathrm{m}^{-1}\right)$ conditions in $\mathrm{S}_{\mathrm{I}}$ and $\mathrm{S}_{\mathrm{II}}$ seasons. Vertical bars represent means \pm S.E $(p \leq 0.05)$. Columns marked by different letters are significantly different.

SI
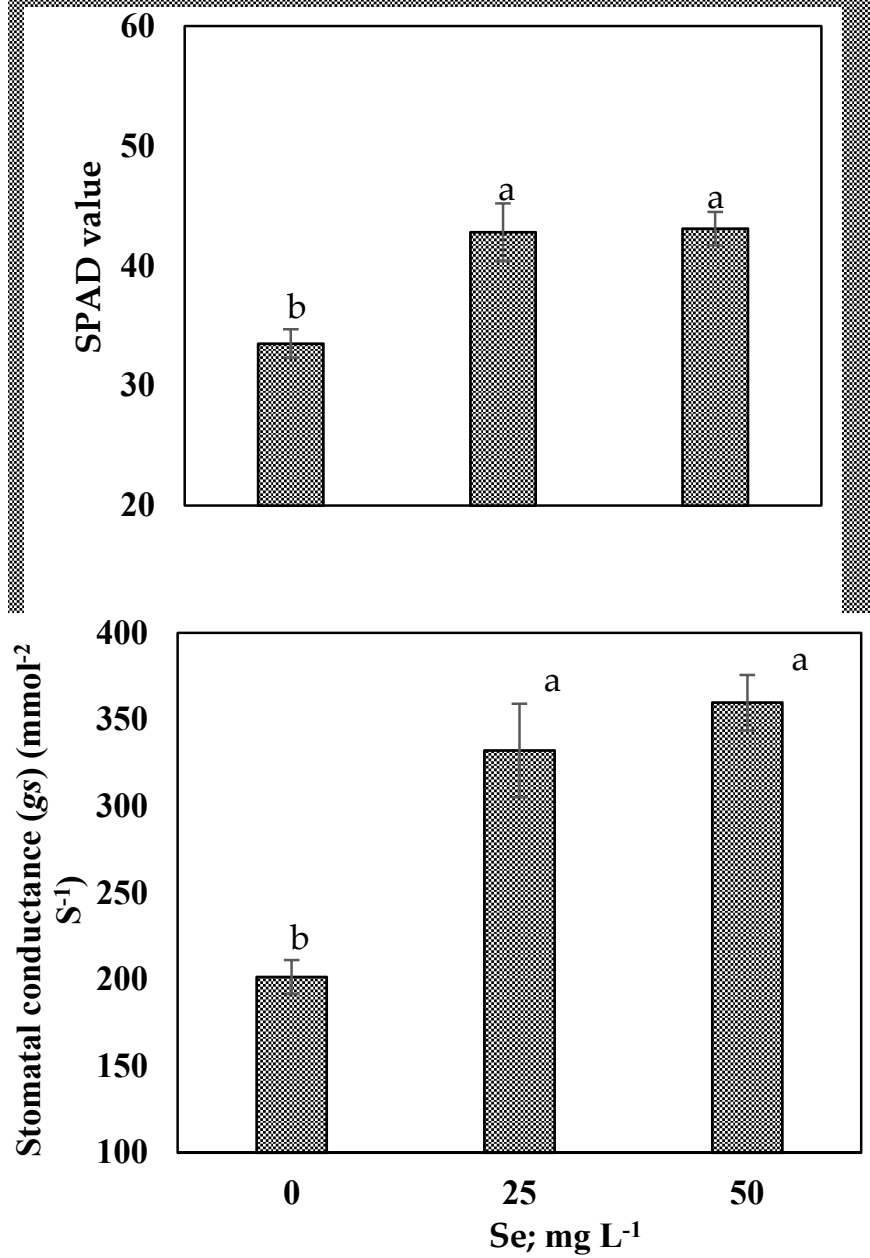

SII
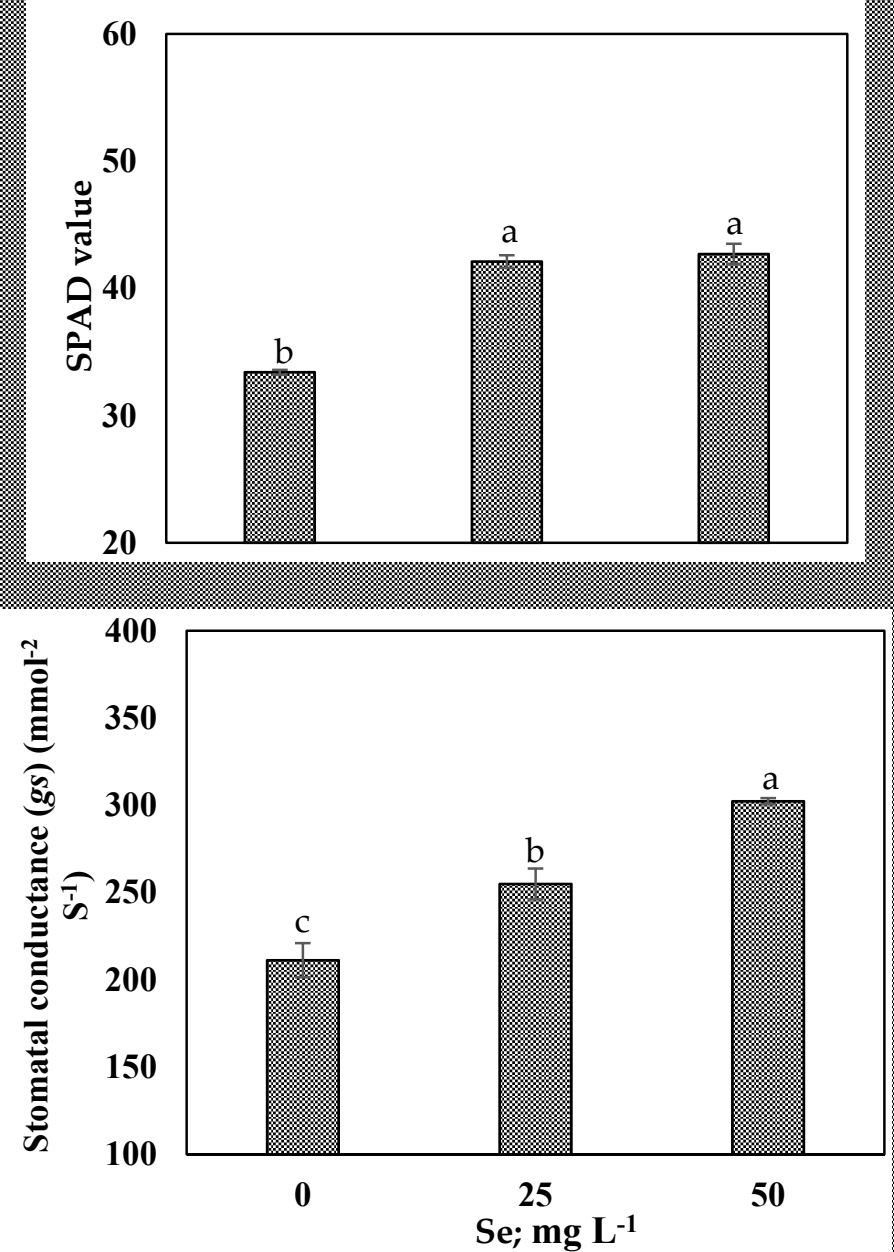

Figure 2. Effects of selenium (Se; $\left.\mathrm{mg} \mathrm{L}^{-1}\right)$ foliar applications on SPAD value and stomatal conductance $\left(g_{s}\right)$ of onion under saline soil $\left(E C=5.2 \mathrm{dS} \mathrm{m}^{-1}\right)$ conditions in $\mathrm{S}_{\mathrm{I}}$ and $\mathrm{S}_{\mathrm{II}}$ seasons. Vertical bars represent means $\pm \mathrm{S} . \mathrm{E}(p \leq 0.05)$. Columns marked by different letters are significantly different. 
Table 5. Effects of foliar applications with selenium (Se) on yield ( $\mathrm{t} / \mathrm{ha}$ ) of different sizes of onion under saline soil $\left(\mathrm{EC}=5.2 \mathrm{dS} \mathrm{m}^{-1}\right.$ ) conditions in 2016/17 (SI) and 2017/18 (SII) seasons.

\begin{tabular}{|c|c|c|c|c|}
\hline \multirow{2}{*}{ Se Treatment } & \multicolumn{3}{|c|}{ Yield ( $t / h a)$ of Different Sizes } & \multirow{2}{*}{$\begin{array}{l}\text { Total Yield } \\
\text { (ton/ha) }\end{array}$} \\
\hline & $\begin{array}{l}<50 \mathrm{~mm} \\
\text { (ton/ha) }\end{array}$ & $\begin{array}{c}50-75 \mathrm{~mm} \\
\text { (ton/ha) }\end{array}$ & $\begin{array}{l}>75 \mathrm{~mm} \\
\text { (ton/ha) }\end{array}$ & \\
\hline \multicolumn{5}{|c|}{ SI } \\
\hline Selenium (Se) & ** & ** & $* *$ & $* *$ \\
\hline $0 \mathrm{mg} \mathrm{L}^{-1}$ & $7.9 \pm 0.3^{\mathrm{a}, \#}$ & $8.3 \pm 0.5^{b}$ & $15.0 \pm 3.1^{b}$ & $31.2 \pm 3.1^{\mathrm{b}}$ \\
\hline $25 \mathrm{mg} \mathrm{L}^{-1}$ & $6.6 \pm 0.8^{b}$ & $12.6 \pm 1.6^{b}$ & $31.4 \pm 2.7^{\mathrm{a}}$ & $50.7 \pm 3.4^{\mathrm{a}}$ \\
\hline $50 \mathrm{mg} \mathrm{L}^{-1}$ & $5.6 \pm 0.9^{b}$ & $15.1 \pm 2.1^{\mathrm{a}}$ & $35.2 \pm 2.8^{\mathrm{a}}$ & $55.9 \pm 1.3^{\mathrm{a}}$ \\
\hline \multicolumn{5}{|c|}{ SII } \\
\hline Selenium (Se) & $* *$ & $* *$ & $* *$ & $* *$ \\
\hline $0 \mathrm{mg} \mathrm{L}^{-1}$ & $8.4 \pm 0.7^{\mathrm{a}}$ & $9.3 \pm 1.9^{c}$ & $14.5 \pm 3.8^{b}$ & $32.1 \pm 1.5^{c}$ \\
\hline $25 \mathrm{mg} \mathrm{L}^{-1}$ & $6.8 \pm 1.3^{b}$ & $11.7 \pm 2.3^{b}$ & $30.9 \pm 1.3^{\mathrm{a}}$ & $49.4 \pm 2.8^{b}$ \\
\hline $50 \mathrm{mg} \mathrm{L}^{-1}$ & $5.4 \pm 1.5^{\mathrm{b}}$ & $19.6 \pm 3.0^{\mathrm{a}}$ & $32.1 \pm 2.4^{\mathrm{a}}$ & $57.0 \pm 1.6^{\mathrm{a}}$ \\
\hline
\end{tabular}

\# Values are means of $(n=9)$. Mean values in each column followed by a different lower case letter are significantly different by Student Newman-Keuls test at $p \leq 0.05 .{ }^{* *}$ and ${ }^{*}$ indicate respective differences at $p \leq 0.05$ and $p \leq 0.01$ probability level.

\subsection{Osmoprotectants and Selenium Contents in Response to Selenium under Salinity Stress}

In both onion leaves and bulbs, choline and total soluble sugars contents were increased by Se supplementation. However, $50 \mathrm{mg} \mathrm{L}^{-1}$ Se-treated plants exhibited higher contents of choline (by $36 \%$ in leaves and $14 \%$ in bulbs) and total soluble sugars (by $21 \%$ in leaves and $6 \%$ in bulbs) than the control (Table 6). However, significant increase in glycine betaine content in leaves of Se-treated plants was observed, whereas application of $25 \mathrm{mg} \mathrm{L}^{-1}$ and $50 \mathrm{mg} \mathrm{L}^{-1}$ Se decreased glycine betaine content in bulbs, when compared to control. Although, free proline content was increased with the application of $25 \mathrm{mg} \mathrm{L}^{-1}$ and $50 \mathrm{mg} \mathrm{L}^{-1}$ Se in onion bulbs by $65 \%$ and $82 \%$, respectively, $25 \mathrm{mg} \mathrm{L}^{-1}$ Se application decreased free proline content in leaves by $35 \%$, relative to non-treated plants (Table 6). Onion plants grown under salt stress without Se application recorded the lowest values of Se content in their leaves and bulbs. Whilst, Se contents were increased in leaves and bulbs of Se-treated plants, highlighting those supplemented with $50 \mathrm{mg} \mathrm{L}^{-1}$, which increased their Se content by 3 folds in leaves and 28 folds in bulbs (Table 6).

Table 6. Effects of foliar applications with selenium (Se) on the leaf and bulb contents of osmoprotectants: choline, glycine betaine (GB), total soluble sugars (TSS), and proline of onion under saline soil (EC $=5.2 \mathrm{dS} \mathrm{m}^{-1}$ ) conditions.

\begin{tabular}{|c|c|c|c|c|c|}
\hline Se Treatment & Choline (mmol g ${ }^{-1}$ DW) & GB $\left(\mathrm{mmol} \mathrm{g}^{-1} \mathrm{DW}\right)$ & TSS (mg g ${ }^{-1}$ DW) & Proline (mg g $\left.{ }^{-1} \mathrm{DW}\right)$ & Se ppm DW \\
\hline \multicolumn{6}{|c|}{ Leaves } \\
\hline Selenium (Se) & $* *$ & * & $* *$ & * & $* *$ \\
\hline $0 \mathrm{mg} \mathrm{L}^{-1}$ & $0.137 \pm 0.001 \mathrm{c}, \#$ & $0.119 \pm 0.003^{c}$ & $1.60 \pm 0.01^{c}$ & $0.187 \pm 0.001^{b}$ & $1.01 \pm 0.002^{c}$ \\
\hline $25 \mathrm{mg} \mathrm{L}^{-1}$ & $0.146 \pm 0.002^{b}$ & $0.225 \pm 0.01^{b}$ & $1.85 \pm 0.01^{b}$ & $0.121 \pm 0.001^{c}$ & $2.12 \pm 0.001^{b}$ \\
\hline $50 \mathrm{mg} \mathrm{L}^{-1}$ & $0.187 \pm 0.001^{\mathrm{a}}$ & $0.311 \pm 0.01^{\mathrm{a}}$ & $1.94 \pm 0.001^{\mathrm{a}}$ & $0.351 \pm 0.001^{\mathrm{a}}$ & $2.89 \pm 0.001^{\mathrm{a}}$ \\
\hline \multicolumn{6}{|c|}{ Bulbs } \\
\hline Selenium (Se) & * & ** & * & ** & $* *$ \\
\hline $0 \mathrm{mg} \mathrm{L}^{-1}$ & $0.492 \pm 0.001^{c}$ & $0.1873 \pm 0.001^{\mathrm{a}}$ & $1.16 \pm 0.01^{b}$ & $0.147 \pm 0.001^{c}$ & $0.001 \pm 0.001^{c}$ \\
\hline $25 \mathrm{mg} \mathrm{L}^{-1}$ & $0.531 \pm 0.01^{\mathrm{b}}$ & $0.1473 \pm 0.001^{b}$ & $1.18 \pm 0.002^{b}$ & $0.242 \pm 0.001^{b}$ & $0.017 \pm 0.001^{b}$ \\
\hline $50 \mathrm{mg} \mathrm{L}^{-1}$ & $0.560 \pm 0.01^{\mathrm{a}}$ & $0.1400 \pm 0.002^{c}$ & $1.23 \pm 0.01^{\mathrm{a}}$ & $0.267 \pm 0.01^{\mathrm{a}}$ & $0.028 \pm 0.003^{a}$ \\
\hline
\end{tabular}

\# Values are means of $(n=5)$. Mean values in each column followed by a different lower case letter are significantly different by Student Newman-Keuls test at $p \leq 0.05 .{ }^{* *}$ and ${ }^{*}$ indicate respective differences at $p \leq 0.05$ and $p \leq 0.01$ probability level.

\subsection{Enzymatic and Non-Enzymatic Antioxidant Activities under Selenium and Salinity Stress}

Exogenous Se application significantly influenced the activity of non-enzymatic and enzymatic antioxidants in onion leaves and bulbs (Table 7). Non-enzymatic antioxidant (i.e., ascorbic acid (AsA) and glutathione (GSH)) activities were elevated in bulbs by both $25 \mathrm{mg} \mathrm{L}^{-1}$ (by $61 \%$ and $126 \%$ for AsA and GSH, respectively) and $50 \mathrm{mg} \mathrm{L}^{-1}$ (by $70 \%$ 
and $147 \%$ for AsA and GSH, respectively), nevertheless, in onion leaves these activities were only elevated with $50 \mathrm{mg} \mathrm{L}^{-1}$ Se application by $63 \%$ for AsA and $134 \%$ for GSH. Compared to salt-stressed plants grown without Se application, Se-treated plants showed higher activities of SOD and CAT, particularly at $50 \mathrm{mg} \mathrm{L}^{-1}$ concentration by $76 \%$ and $50 \%$ (in leaves), respectively, and $99 \%$ and $68 \%$ (in bulbs), respectively. Externally applied $25 \mathrm{mg} \mathrm{L}^{-1}$ or $50 \mathrm{mg} \mathrm{L}^{-1}$ Se up-regulated APX activity particularly in bulbs by $122 \%$ (on average), but both Se levels were significantly or non-significantly reduced by GR activity.

Table 7. Effects of foliar applications with selenium (Se) on the activity of leaf and bulb non-enzymatic; ascorbic acid (AsA) and glutathione (GSH) and enzymatic; ascorbate peroxidase (APX), superoxide dismutase (SOD), catalase (CAT), and glutathione reductase (GR) antioxidants of onion under saline soil $\left(\mathrm{EC}=5.2 \mathrm{dS} \mathrm{m}^{-1}\right)$ conditions.

\begin{tabular}{|c|c|c|c|c|c|c|}
\hline \multirow{2}{*}{ Se Treatment } & AsA Content & GSH Content & APX & SOD Activity & CAT Activity & GR \\
\hline & \multicolumn{2}{|c|}{ (mmol g ${ }^{-1}$ Fresh Weight) } & \multicolumn{4}{|c|}{ ( $\mu \mathrm{mol} \mathrm{mg}^{-1}$ Protein) } \\
\hline \multicolumn{7}{|c|}{ Leaves } \\
\hline Selenium (Se) & $* *$ & $* *$ & $* *$ & $* *$ & * & * \\
\hline $0 \mathrm{mg} \mathrm{L}^{-1}$ & $0.067 \pm 0.002^{c, \#}$ & $0.038 \pm 0.01^{\mathrm{b}}$ & $0.061 \pm 0.001^{b}$ & $0.181 \pm 0.001^{\mathrm{c}}$ & $0.074 \pm 0.01^{\mathrm{b}}$ & $0.311 \pm 0.01^{\mathrm{a}}$ \\
\hline $25 \mathrm{mg} \mathrm{L}^{-1}$ & $0.081 \pm 0.001^{b}$ & $0.060 \pm 0.003^{b}$ & $0.064 \pm 0.001^{\mathrm{a}}$ & $0.207 \pm 0.01^{b}$ & $0.106 \pm 0.01^{\mathrm{a}}$ & $0.256 \pm 0.02^{a, b}$ \\
\hline $50 \mathrm{mg} \mathrm{L}^{-1}$ & $0.109 \pm 0.001^{\mathrm{a}}$ & $0.089 \pm 0.01^{\mathrm{a}}$ & $0.064 \pm 0.001^{\mathrm{a}}$ & $0.318 \pm 0.01^{\mathrm{a}}$ & $0.111 \pm 0.002^{\mathrm{a}}$ & $0.213 \pm 0.01^{b}$ \\
\hline \multicolumn{7}{|c|}{ Bulbs } \\
\hline Selenium (Se) & $* *$ & $* *$ & $* *$ & $* *$ & $* *$ & NS \\
\hline $0 \mathrm{mg} \mathrm{L}^{-1}$ & $0.149 \pm 0.01^{b}$ & $0.043 \pm 0.01^{b}$ & $0.023 \pm 0.001^{b}$ & $0.144 \pm 0.01^{\mathrm{c}}$ & $0.056 \pm 0.01^{\mathrm{c}}$ & $0.225 \pm 0.01^{\mathrm{a}}$ \\
\hline $25 \mathrm{mg} \mathrm{L}^{-1}$ & $0.240 \pm 0.01^{\mathrm{a}}$ & $0.097 \pm 0.001^{\mathrm{a}}$ & $0.052 \pm 0.001^{\mathrm{a}}$ & $0.188 \pm 0.01^{\mathrm{b}}$ & $0.077 \pm 0.001^{b}$ & $0.203 \pm 0.03^{a}$ \\
\hline $50 \mathrm{mg} \mathrm{L}^{-1}$ & $0.254 \pm 0.002^{\mathrm{a}}$ & $0.106 \pm 0.001^{\mathrm{a}}$ & $0.050 \pm 0.001^{\mathrm{a}}$ & $0.287 \pm 0.01^{\mathrm{a}}$ & $0.094 \pm 0.003^{\mathrm{a}}$ & $0.201 \pm 0.04^{\mathrm{a}}$ \\
\hline
\end{tabular}

\# Values are means of $(n=5)$. Mean values in each column followed by a different lower case letter are significantly different by Student Newman-Keuls test at $p \leq 0.05 .{ }^{* *}$ and * indicate respective differences at $p \leq 0.05$ and $p \leq 0.01$ probability level, and "NS" indicates not significant difference.

\subsection{Correlation Analysis}

Table 8 presents the correlation coefficient between onion yield and other important traits for both growing seasons. This type of analysis can be used as a suitable tool to regulate any trait of them is positive and closely related to the bulb's yield obtained. The correlation coefficient indicated a strong positive correlation ( $\mathrm{r}$ between 0.674-0.972) between bulb's yield and other traits. Results of Table 9 exhibited that SPAD, PI, and leaves area in SI and Fresh weight, SPAD, and leaves number in SII, strongly contributed to variations in bulb's yield.

Table 8. A matrix of simple correlation coefficient between onion yield and other important traits estimated in 2016/17 (SI) and 2017/18 (SII) seasons.

\begin{tabular}{|c|c|c|c|c|c|c|c|c|c|c|c|c|}
\hline & Parameter & Season & 1 & 2 & 3 & 4 & 5 & 6 & 7 & 8 & 9 & 10 \\
\hline \multirow{2}{*}{1} & \multirow{2}{*}{ Bulb's yield } & SI & 1 & & & & & & & & & \\
\hline & & SII & 1 & & & & & & & & & \\
\hline \multirow{2}{*}{2} & \multirow{2}{*}{ Plant height } & SI & $0.723 * *$ & 1 & & & & & & & & \\
\hline & & SII & $0.908 * *$ & 1 & & & & & & & & \\
\hline \multirow{2}{*}{3} & \multirow{2}{*}{ Leaves No } & SI & $0.759 * *$ & $0.584^{* *}$ & 1 & & & & & & & \\
\hline & & SII & $0.674^{* *}$ & $0.720 * *$ & 1 & & & & & & & \\
\hline \multirow[b]{2}{*}{4} & \multirow[b]{2}{*}{ Leaf area } & SI & $0.846^{* *}$ & $0.708^{* *}$ & $0.803^{* *}$ & 1 & & & & & & \\
\hline & & SII & $0.939 * *$ & $0.895^{* *}$ & $0.772 * *$ & 1 & & & & & & \\
\hline \multirow{2}{*}{5} & \multirow{2}{*}{ Shoot fresh weight } & SI & $0.906^{* *}$ & $0.777^{* *}$ & $0.792^{* *}$ & $0.969 * *$ & 1 & & & & & \\
\hline & & SII & $0.881 * *$ & $0.890 * *$ & $0.81 * *$ & $0.880 * *$ & 1 & & & & & \\
\hline \multirow[b]{2}{*}{6} & & SI & $0.894^{* *}$ & $0.780 * *$ & $0.521 * *$ & $0.695^{* *}$ & $0.766^{* *}$ & 1 & & & & \\
\hline & $F_{v} / F_{m}$ & SII & $0.907 * *$ & $0.818^{* *}$ & $0.660^{* *}$ & 0.903 ** & $0.798 * *$ & 1 & & & & \\
\hline \multirow{2}{*}{7} & \multirow{2}{*}{ PI } & SI & $0.801 * *$ & $0.671^{* *}$ & 0.377 & $0.582 *$ & $0.702 * *$ & $0.892^{* *}$ & 1 & & & \\
\hline & & SII & $0.904 * *$ & $0.802 * *$ & $0.608^{*}$ & 0.782 ** & $0.795^{* *}$ & $0.717^{* *}$ & 1 & & & \\
\hline \multirow{2}{*}{8} & \multirow{2}{*}{ SPAD } & SI & $0.779 * *$ & 0.455 & $0.563 *$ & $0.563 *$ & $0.621 *$ & $0.675^{* *}$ & 0.441 & 1 & & \\
\hline & & SII & $0.972 * *$ & $0.893^{* *}$ & $0.660^{* *}$ & $0.921 * *$ & $0.868^{* *}$ & $0.959 * *$ & $0.844^{* *}$ & 1 & & \\
\hline \multirow[b]{2}{*}{9} & \multirow{2}{*}{ RWC } & SI & $0.873^{* *}$ & $0.694^{* *}$ & $0.759^{* *}$ & $0.536^{*}$ & $0.785^{* *}$ & $0.740 * *$ & $0.526^{* *}$ & $0.869 * *$ & 1 & \\
\hline & & SII & $0.888^{* *}$ & $0.799 * *$ & $0.651^{* *}$ & $0.919^{* *}$ & $0.833^{* *}$ & $0.939^{* *}$ & $0.700^{* *}$ & $0.913^{* *}$ & 1 & \\
\hline \multirow{2}{*}{10} & \multirow{2}{*}{ MSI } & SI & $0.754^{* *}$ & 0.391 & $0.766^{* *}$ & $0.637^{*}$ & $0.690^{* *}$ & 0.623 * & 0.360 & 0.789 ** & 0.742 ** & 1 \\
\hline & & SII & $0.776^{* *}$ & 0.606 * & 0.486 & $0.705^{* *}$ & $0.646^{* *}$ & $0.762^{* *}$ & $0.628 *$ & $0.742^{* *}$ & $0.836^{* *}$ & 1 \\
\hline
\end{tabular}

** and * indicate correlation is significant at the 0.01 level and at the 0.05 level, respectively. 
Table 9. Correlation coefficient $(r)$, coefficient of determination $\left(R^{2}\right)$, and standard error of the estimates (SEE) for predicting onion yield for SI (2016/17) and SII $(2017 / 18)$ seasons.

\begin{tabular}{cccccc}
\hline Season & $\boldsymbol{r}$ & $\boldsymbol{R}^{\mathbf{2}}$ & SEE & Significance & Fitted Equation \\
\hline SI & 0.990 & 0.980 & 1.80 & $* *$ & Bulb's yield $=-11.02+1.1$ SPAD +1.25 PI +0.523 leaves area \\
SII & 0.990 & 0.980 & 1.67 & $* *$ & Bulb's yield $=-16.83+0.058$ FW +0.63 SPAD +1.28 PI + leaves No \\
\hline
\end{tabular}

\section{Discussion}

At present, soil salinity has stood out as an important problem threatening agriculture production worldwide. In different plant species, salinity stress has been shown to extensively hinder plant growth and production [15,57-60].

In the present study, the tested soil has a salinity of $5.27 \mathrm{dS} \mathrm{m}^{-1}$ and led to the exposure of onion plants to salt stress. This salt-stressed onion induces not only reduction of plant water status (in terms of MSI and RWC), but also decreased stomatal conductance and the photosynthetic efficiency (Table 4; Figures 1 and 2), which reflected negatively in onion growth, namely shoot length, leaf number, leaf area, and plant biomass (Table 3), and consequently declines of onion yields (Table 5). Saline soil may upset the nutrients balance in plant and interfere uptake of necessary nutrients leading to nutrient deficiency [16], that inhibits or delay development of onion roots, shoots (Table 3), and bulb enlargement, thence negatively affected bulb yields (Table 5). At the cellular level, salt stress arrest cell cycle through downregulation of the activity/expression of some protein kinase enzymes, precisely cyclins and cyclin-dependent kinases, resulting in fewer meristematic cells, in which diminish plant growth traits [6]. However, our study exhibited that the negative effects on growth traits of salt-stressed onion were alleviated by foliar-applied Se in particular, $50 \mathrm{mg} \mathrm{L}^{-1}$, thereby enhanced shoot length, leaf area, and number of leaves per plant; additionally, Se increased onion biomass production grown under salinity stress. The enhancement of the onion dry biomass by exogenous Se may be a positive criterion for salt tolerance correlates with an increase of the yields [7], hence plant produces more metabolites that required for onion growth.

Salinity stress indirectly suppresses onion growth and productivity via induced reductions in cell division and elongation leading to a decrease of the leaf area (Table 3), concurrently with reduction of stomatal conductance and decreases of photosynthetic efficiency of PSII (Figures 1 and 2) [13,61]. Gas exchange control is the responsibility of stomatal conductance, it responds quickly when the plant is subjected to salinity stress [13]. In this research, salt-stressed plants experienced a reduction of stomatal conductance (Figure 2), consequently this may reduce the intercellular $\mathrm{CO}_{2}$ and net photosynthesis, according to [61]. Along with the reduction of leaf relative chlorophyll content (SPAD value), salinity stress decreased the maximum quantum yield of PSII $\left(F_{v} / F_{m}\right)$, PSII $F_{v} / F_{0}$ ratio, and PI (Figure 1). The reduction of the $F_{v} / F_{m}$ was obtained as a decrease of $F_{m}$, that represent photo inhibition of PSII [62], while the activity of PSII reaction centers $\left(F_{v} / F_{0}\right)$ decreased due to increase of $F_{0}$, indicating the damage occurred in the photosynthetic apparatus and the electron transport chain $[63,64]$, all collectively indicating the damage in the light-harvesting complex of PSII in salt-stressed onion plants. Otherwise, the Se application improved the tolerance of onion to salinity stress, showing that Se increased relative chlorophyll content (SPAD value) and the efficiency of chlorophyll fluorescence synchronized with increase stomatal conductance of onion under salt stress (Figure 1). These improvements in relative chlorophyll content (SPAD value) and photosynthetic efficiency by Se supplementation was also observed in onion [65], maize [27], and tomato [19] under salt stress. These findings may be linked with maintaining cell membrane integrity and increase tissues RWC by foliar spraying Se salt-stressed plants that restore structure of the damaged chloroplasts. Further, Se could stimulate the chlorophyll biosynthesis and increase chlorophyll content, hence increase the photosynthetic capacity. Furthermore, restoration of photosynthetic efficiency in stressed plants by exogenous Se application 
could be attributed to increase in osmoprotectants contents (Table 6) and antioxidant activity (Table 7). These plants' defense system components involved in detoxifying of ROS generated by salinity stress and prevents chlorophyll degradation $[28,66]$.

RWC is closely related to cell turgor, the process in which driving cell division and expansion, whereas MSI is used to estimate the degree of injuries induced by stressors [67]. In this research, the reductions in both MSI and RWC obtained in salt-affected plants (Table 4), indicating the detrimental effects of salinity stress on onion plants. It's well documented that salinity stress-induced ROS formation causes lipid peroxidation, owing to decreases of membrane integrity and loss of cell turgor [68]. However, these negative responses of increased cell membrane injuries, and reduction of RWC triggered by salt stress, were alleviated by exogenously-applied Se (Table 4), in line with the findings obtained by [19]. Tissue water status promoting in Se-treated plants may be related to stimulated root growth and its capacity for water uptake [69]. Therefore, our results confirm that Se plays a role in stabilizing membrane integrity and maintains cell turgor under salinity stress. In this regard, increases of MSI and tissue RWC as metabolically available water, helping in maintaining tissue health and maybe reflect on the metabolic processes in onion plants [70].

Our data showed that externally-applied Se markedly enhanced tissue water status, relative chlorophyll content (SPAD value), photosynthetic efficiency, growth traits, and biomass production of onion cultivated in salt-affected soil (Table 4; Figures 1 and 2), which reflected consequently on a considerable increase of bulb yield and WUE (Table 4). Similar effects of Se on onion bulb yield have been reported by [65], who noticed that foliar application of Se to onion plants grown under both salt-affected soil and irrigated with saline water of $4 \mathrm{dS} \mathrm{m}^{-1}$ increased onion bulb yield and large bulb percentage. It was interestingly found in this study that Se improved WUE by approximately twofold compared to non-Se-treated plants, due to the increase of bulb yield. Saline soil affects WUE, owing to the ion toxicity and the decrease water availability, as well as RWC, photosynthetic efficiency, and onion yield [71], thereby increased as a result of exogenous Se application, as observed in this study. Correlation analysis indicated the Bulb yield was positively correlated with the other traits. This type of analysis can be used as a suitable tool to regulate any trait of them is positive and closely related to the Bulbs yield obtained [72]. In this study, significant correlations were observed among traits revealing the link between vegetative growth, photosynthetic capacity, plant water status, and the bulb yield of onion.

Endogenous Se contents increased by foliar-applied Se in leaves and bulbs of saltstressed onion plants, which might be due to improved activities of the antioxidant defense molecules. Our results are concordant with that reported by [27], which showed that Se supplementation increased Se content in shoots of maize plants under salinity stress.

Onion plants in this study produced more osmoprotectants like choline, soluble sugars, proline, and glycine betaine with the application of $50 \mathrm{mg} \mathrm{L}^{-1}$ Se (Table 6). In response to salt stress, plants react by accumulating more osmotically active solutes/osmoprotectants, such as proline, choline, soluble sugars, and glycine betaine. These osmoprotectants jointly, with endogenous $\mathrm{Se}$, contribute in salt stress tolerance by osmotic regulation role for protection of the thylakoid membrane [73], maintenance turgor pressure, thus preventing oxidative damage and photoinhibition, hence improved photosynthetic efficiency [11]. Refs. $[19,22,74]$ has noticed an accumulation of osmoprotectants by Se application for maintaining tissues water status in stressed plants, increasing RWC, as described by [19]. Osmotically-stressed plants sprayed with Se significantly increased its content from choline and glycine betaine (Table 6), this might be related to how Se up-regulates biosynthesis of choline/choline monooxygenase enzyme, which catalyzes the synthesis of glycine betaine [74].

Under salt stress in this study, clear increases in AsA and GSH contents were observed in the Se-treated plant compared to the control (Table 7). Se mediated increase of AsA and GSH were also observed in tomato under drought [19] and salinity $[75,76]$ stress and wheat under cadmium stress [77], indicating an improvement in the AsA-GSH cycle as an effective 
mechanism in scavenging ROS to alleviates the oxidative damages in cellular organelles under abiotic stress [76-79]. AsA is viewed as the most remarkable ROS scavenger, in light of its capacity to denote electrons in various enzymatic and non-enzymatic responses [80]. The activity of AsA and GSH largely correlated with regeneration and synthesis of the four enzymes DHAR, GR and MDHAR, and APX [80]. Thus, the balance of the AsA and GSH pool is linked with the activity of APX, that increased by Se application under this study (Table 7). Besides GSH directly detoxifying the ROS and maintaining the redox state in the AsA-GSH cycle, it plays a central role in the antioxidant defense system because of its capacity to regenerate AsA by reducing of DHA in the AsA-GSH cycle [79,80]. Se may also participate in the regeneration of AsA by up-regulating the associated enzymes, i.e., MDHAR and DHAR [80].

Our results exhibited that exogenous Se application markedly elevated the activity of the antioxidant enzymes like APX, SOD, and CAT in onion leaves and bulbs, and GR only increased in onion leaves under salinity stress (Table 7). The activity of these enzymes is important for the detoxification of ROS in plant tissues, which helps to reduce the biomarkers of oxidative stress under salt stress. All the more explicitly, the activity levels and the balance between SOD and APX, or CAT activities in cells, are viewed as basic for deciding the steady-state level of $\mathrm{O}_{2}{ }^{-}$and $\mathrm{H}_{2} \mathrm{O}_{2}$ to prevent the formation of the highly toxic $\mathrm{OH}^{-}$[81]. In the enzymatic antioxidant defense system, SOD found in the frontline to scavenge ROS by dismuting $\mathrm{O}_{2}{ }^{-}$to $\mathrm{H}_{2} \mathrm{O}_{2}$ in the water-water cycle, the AsA-GSH cycle, and the glutathione-peroxidase cycle. Posteriorly, APX utilizes AsA as an electron donor in converting $\mathrm{H}_{2} \mathrm{O}_{2}$ to $\mathrm{H}_{2} \mathrm{O}$ as a part of the AsA-GSH cycle and the water-water cycle, also CAT scavenge $\mathrm{H}_{2} \mathrm{O}_{2}$ to $\mathrm{H}_{2} \mathrm{O}$ for ROS detoxification in peroxisomes during stress $[79,81]$. Results of the present study exhibited that under salinity stress, the activities of enzymatic and non-enzymatic antioxidants increased by Se application (Table 7), in coincidence with a reduction in cell membrane injury, increases in RWC, stomatal conductance, and photosynthetic efficiency (Table 4; Figures 1 and 2). Thus, our findings suggest that Se alleviates salt stress on onion by enhancing the antioxidant activities. On the other hand, in a cytotoxicity study of Nano-Se (Se NP) on two types of human cell line, Se NP had the ability to increase percentage of growth inhibition of the tested cell lines via the induction of low molecular weight proteins, associated with total antioxidant value in seed of Nano-Se treated plants and vice versa, evidencing safety of the yield for human health [82]. Similar findings were also reported by $[83,84]$.

\section{Conclusions}

Based on these results, it could be concluded that exogenous Se application showed a considerable potential positive effect to mitigate salt stress on onion plants, in the view of enhancing growth and productivity and improving water use efficiency via Se-mediated cell integrity (MSI) and maintained cell turgor (RWC). The protective role of Se could be also associated with the enhancement of enzymatic (APX, SOD, and CAT), and non-enzymatic (AsA and GSH) antioxidants, which together, increased osmoprotectants (proline, glycine betaine, choline, and soluble sugars) up-regulation and enhanced the photosynthetic efficiency. Se foliar application may therefore find in future a potential application as anti-abiotic stresses for minimizing the deleterious effects of salinity.

Author Contributions: Conceptualization, W.M.S., M.O.A.R., and T.A.A.E.-M.; methodology, W.M.S., S.M.H. and M.O.A.R.; formal analysis, T.A.A.E.-M., A.A. and W.M.S.; investigation, W.M.S., T.A.A.E.M., H.A.A., K.A.H. and A.A.A.L.; resources W.M.S., T.A.A.E.-M., H.A.A., K.A.H., A.A.A.L., S.M.H. and M.O.A.R.; data curation, W.M.S., A.A., A.A.A.L. and T.A.A.E.-M.; writing-original draft preparation, A.A., W.M.S. and T.A.A.E.-M.; writing-review and editing, A.A., W.M.S., A.A.A.L. and T.A.A.E.-M.; visualization, W.M.S., A.A., S.M.H. and T.A.A.E.-M.; supervision, W.M.S., M.O.A.R., A.A. and T.A.A.E.-M.; project administration, W.M.S., M.O.A.R. and T.A.A.E.-M. All authors have read and agreed to the published version of the manuscript.

Funding: This research received no external funding. 
Data Availability Statement: All the data generated or analyzed during the current study are included in the published article.

Conflicts of Interest: The authors declare no conflict of interest.

\section{References}

1. Ricciardi, L.; Mazzeo, R.; Marcotrigiano, A.R.; Rainaldi, G.; Iovieno, P.; Zonno, V.; Pavan, S.; Lotti, C. Assessment of genetic diversity of the "acquaviva red onion" (Allium cepa L.) apulian landrace. Plants 2020, 9, 260. [CrossRef] [PubMed]

2. FAOSTAT. Food and Agriculture Data; Food and Agriculture Organization: Roma, Italy, 2019.

3. Maas, E.V.; Grattan, S.R. Crop yields as affected by salinity. Agronomy 1999, 38, 55-110.

4. Rady, M.O.A.; Semida, W.M.; El-mageed, T.A.A.; Hemida, K.A.; Rady, M.M. Up-regulation of antioxidative defense systems by glycine betaine foliar application in onion plants confer tolerance to salinity stress. Sci. Hortic. 2018, 240, 614-622. [CrossRef]

5. Semida, W.M.; Abdelkhalik, A.; Rady, M.O.A.; Marey, R.A.; El-Mageed, T.A.A. Exogenously applied proline enhances growth and productivity of drought stressed onion by improving photosynthetic efficiency, water use efficiency and up-regulating osmoprotectants. Sci. Hortic. 2020, 272, 109580. [CrossRef]

6. Shrivastava, P.; Kumar, R. Soil salinity: A serious environmental issue and plant growth promoting bacteria as one of the tools for its alleviation. Saudi J. Biol. Sci. 2015, 22, 123-131. [CrossRef]

7. Majeed, A.; Muhammad, Z. Salinity: A major agricultural problem-Causes, impacts on crop productivity and management strategies. In Plant Abiotic Stress Tolerance Agronomic, Molecular and Biotechnological Approaches; Hasanuzzaman, M., Hakeem, K.R., Nahar, K., Alharby, H.F., Eds.; Springer Nature: Cham, Switzerland, 2019; p. 490. ISBN 9783030061173.

8. Desoky, E.M.; El-Maghraby, L.M.M.; Awad, A.E.; Abdo, A.I.; Rady, M.M.; Semida, W.M. Fennel and ammi seed extracts modulate antioxidant defence system and alleviate salinity stress in cowpea (Vigna unguiculata). Sci. Hortic. 2020, 272, 109576. [CrossRef]

9. Semida, W.M.; El-Mageed, T.A.A.; Mohamed, S.E.; El-Sawah, N.A. Combined effect of deficit irrigation and foliar-applied salicylic acid on physiological responses, yield, and water-use efficiency of onion plants in saline calcareous soil. Arch. Agron. Soil Sci. 2017, 63, 1227-1239. [CrossRef]

10. Semida, W.M.; Abd El-Mageed, T.A.; Howladar, S.M.; Mohamed, G.F.; Rady, M.M. Response of Solanum melongena L. seedlings grown under saline calcareous soil conditions to a new organo-mineral fertilizer. J. Anim. Plant Sci. 2015, 25, 485-493.

11. Singh, M.; Kumar, J.; Singh, S.; Singh, V.P.; Prasad, S.M. Roles of osmoprotectants in improving salinity and drought tolerance in plants: A review. Rev. Environ. Sci. Biotechnol. 2015, 14, 407-426. [CrossRef]

12. Rady, M.M.; Taha, R.S.; Semida, W.M.; Alharby, H.F. Modulation of salt stress effects on vicia faba 1. plants grown on a reclaimed-saline soil by salicylic acid application. Rom. Agric. Res. 2017, 34, 175-185.

13. Munns, R.; Tester, M. Mechanisms of Salinity Tolerance. Annu. Rev. Plant Biol. 2008, 59, 651-681. [CrossRef]

14. Moustafa, E.S.A.; El-Sobky, E.-S.E.A.; Farag, H.I.A.; Yasin, M.A.T.; Attia, A.; Rady, M.O.A.; Awad, M.F.; Mansour, E. Sowing Date and Genotype Influence on Yield and Quality of Dual-Purpose Barley in a Salt-Affected Arid Region. Agronomy 2021, 11, 717. [CrossRef]

15. Semida, W.M.; Abd El-mageed, T.A.; Howladar, S.M.; Rady, M.M. Foliar-applied a-tocopherol enhances salt-tolerance in onion plants by improving antioxidant defence system. Aust. J. Crop Sci. 2016, 10, 1030-1039. [CrossRef]

16. Gupta, B.; Huang, B. Mechanism of salinity tolerance in plants: Physiological, biochemical, and molecular characterization. Int. J. Genom. 2014, 2014. [CrossRef] [PubMed]

17. Semida, W.M.; Hemida, K.A.; Rady, M.M. Sequenced ascorbate-proline-glutathione seed treatment elevates cadmium tolerance in cucumber transplants. Ecotoxicol. Environ. Saf. 2018, 154, 171-179. [CrossRef] [PubMed]

18. Nawaz, F.; Naeem, M.; Ashraf, M.Y.; Tahir, M.N.; Zulfiqar, B.; Salahuddin, M.; Shabbir, R.N.; Aslam, M. Selenium supplementation affects physiological and biochemical processes to improve fodder yield and quality of maize (Zea mays L.) under water deficit conditions. Front. Plant Sci. 2016, 7, 1438. [CrossRef] [PubMed]

19. Rady, M.M.; Belal, H.E.E.; Gadallah, F.M.; Semida, W.M. Selenium application in two methods promotes drought tolerance in Solanum lycopersicum plant by inducing the antioxidant defense system. Sci. Hortic. 2020, 266, 109290. [CrossRef]

20. Gupta, M.; Gupta, S. An Overview of Selenium Uptake, Metabolism, and Toxicity in Plants. Front. Plant Sci. 2017, 7. [CrossRef] [PubMed]

21. Li, H.; Liu, X.; Wassie, M.; Chen, L. Selenium supplementation alleviates cadmium-induced damages in tall fescue through modulating antioxidant system, photosynthesis efficiency, and gene expression. Environ. Sci. Pollut. Res. 2020, 27, 9490-9502. [CrossRef] [PubMed]

22. Nawaz, F.; Ahmad, R.; Ashraf, M.Y.; Waraich, E.A.; Khan, S.Z. Effect of selenium foliar spray on physiological and biochemical processes and chemical constituents of wheat under drought stress. Ecotoxicol. Environ. Saf. 2015, 113, 191-200. [CrossRef]

23. Kamran, M.; Parveen, A.; Ahmar, S.; Hussain, S.; Chattha, M.S.; Saleem, M.H.; Adil, M.; Heidari, P.; Chen, J. An Overview of Hazardous Impacts of Soil Salinity in Crops, Tolerance Mechanisms, and Amelioration through Selenium Supplementation. Int. J. Mol. Sci. 2020, 21, 148. [CrossRef]

24. Kápolna, E.; Laursen, K.H.; Husted, S.; Larsen, E.H. Bio-fortification and isotopic labelling of Se metabolites in onions and carrots following foliar application of Se and 77 Se. Food Chem. 2012, 133, 650-657. [CrossRef]

25. Jóźwiak, W.; Politycka, B. Effect of selenium on alleviating oxidative stress caused by a water deficit in cucumber roots. Plants 2019, 8, 217. [CrossRef] 
26. Yin, H.; Qi, Z.; Li, M.; Jalal, G.; Chu, X.; Zhou, J. Selenium forms and methods of application differentially modulate plant growth, photosynthesis, stress tolerance, selenium content and speciation in Oryza sativa L. Ecotoxicol. Environ. Saf. 2019, 169, 911-917. [CrossRef]

27. Jiang, C.; Zu, C.; Lu, D.; Zheng, Q.; Shen, J.; Wang, H. Effect of exogenous selenium supply on photosynthesis, Na + accumulation and antioxidative capacity of maize (Zea mays L.) under salinity stress. Sci. Rep. 2017, 7, 42039. [CrossRef] [PubMed]

28. Feng, R.; Wei, C.; Tu, S. The roles of selenium in protecting plants against abiotic stresses. Environ. Exp. Bot. 2013, 87, 58-68. [CrossRef]

29. Ashraf, M.A.; Akbar, A.; Parveen, A.; Rasheed, R.; Hussain, I. Plant physiology and biochemistry phenological application of selenium differentially improves growth, oxidative defense and ion homeostasis in maize under salinity stress. Plant Physiol. Biochem. 2018, 123, 268-280. [CrossRef] [PubMed]

30. Ponce, V.M.; Pandey, R.P.; Ercan, S. Characterization of drought across climatic spectrum. J. Hydrol. Eng. 2000, 5, 222-224. [CrossRef]

31. Allen, R.G.; Pereira, L.S.; Raes, D.; Smith, M. Crop Evapotranspiration: Guidelines for Computing Crop Requirements, Irrigation and Drainage Paper No. 56; FAO: Rome, Italy, 1998.

32. Israelsen, O.W.; Hansen, V.C. Irrigation Principles and Practices; John Wiley \& Sons Inc.: New York, NY, USA, 1962.

33. Klute, A.; Dirksen, C. Hydraulic conductivity and diffusivity. Laboratory methods. Methods Soil Anal. 1986, 9, 687-734.

34. Page, A.L.; Miller, R.H.; Keeney, D.R. Methods of Soil Analysis Part 2. Chemical and Microbiological Properties; American Society of Agronomy, Inc.: Madison, WI, USA, 1982.

35. Soil Survey Staff. Keys to Soil Taxonomy, 12th ed.; USDA-NRCS: Washington, DC, USA, 2014; ISBN 0926487221.

36. Dahnke, W.C.; Whitney, D.A. Measurement of soil salinity. In Recommended Chemical Soil Test Procedures for the North Central Region; Dahnke, W.C., Ed.; North Central Regional Publication 221; North Dakota Agricultural Experiment Station: St. Bull, ND, USA, 1988; Volume 499, pp. 32-34.

37. Horwitz, W. (Ed.) AOAC Official Methods of Analysis of AOAC International; Association of Official Analytical Chemists: Washington, DC, USA, 1995; Volume II, pp. 1058-1059, ISBN 0935584544.

38. Jensen, M.E. Design and Operation of Farm Irrigation Systems; American Society of Agricultural Engineers: St. Joseph, MI, USA, 1983; p. 827.

39. Maxwell, K.; Johnson, G.N. Chlorophyll fluorescence-A practical guide. J. Exp. Bot. 2000, 51, 659-668. [CrossRef]

40. Spoustová, P.; Synková, H.; Valcke, R.; Čevrovská, N. Chlorophyll a fluorescence as a tool for a study of the Potato virus Y effects on photosynthesis of nontransgenic and transgenic Pssu-ipt tobacco. Photosynthetica 2013, 51, 191-201. [CrossRef]

41. Clark, A.J.J.; Landolt, W.; Bucher, J.B.B.; Strasser, R.J.J. Beech (Fagus sylvatica) response to ozone exposure assessed with a chlorophyll a fluorescence performance index. Environ. Pollut. 2000, 109, 501-507. [CrossRef]

42. Premachandra, G.S.; Saneoka, H.; Ogata, S. Cell membrane stability, an indicator of drought tolerance, as affected by applied nitrogen in soyabean. J. Agric. Sci. 1990, 115, 63-66. [CrossRef]

43. Rady, M.M. Effect of 24-epibrassinolide on growth, yield, antioxidant system and cadmium content of bean (Phaseolus vulgaris L.) plants under salinity and cadmium stress. Sci. Hortic. 2011, 129, 232-237. [CrossRef]

44. Weatherley, P.E. Studies in the water relations of cotton. 1. The field measurement of water deficits in leaves. New Phytol. 1950, 49, 81-97. [CrossRef]

45. Osman, A.S.; Rady, M.M. Effect of humic acid as an additive to growing media to enhance the production of eggplant and tomato transplants. J. Hortic. Sci. Biotechnol. 2014, 89, 237-244. [CrossRef]

46. Bates, L.; Waldren, R.; Teare, I. Rapid determination of free proline for water-stress studies. Plant Soil 1973, $207,205-207$. [CrossRef]

47. Irigoyen, J.J.; Einerich, D.W.; Sánchez-Díaz, M. Water stress induced changes in concentrations of proline and total soluble sugars in nodulated alfalfa (Medicago sativd) plants. Physiol. Plant 1992, 84, 55-60. [CrossRef]

48. Subbarao, G.V.; Wheeler, R.M.; Stutte, G.W.; Levine, L.H. How far can sodium substitute for potassium in red beet? J. Plant Nutr. 1999, 22, 1745-1761. [CrossRef]

49. Bessieres, M.A.; Gibon, Y.; Lefeuvre, J.C.; Larher, F. A single-step purification for glycine betaine determination in plant extracts by isocratic HPLC. J. Agric. Food Chem. 1999, 47, 3718-3722. [CrossRef]

50. AOAC Official Methods of Analysis, 17th ed.; The Association of Official Analytical Chemists: Gaithersburg, MD, USA, 2000; ISBN 0935584676.

51. Mukherjee, S.P.; Choudhuri, M.A. Implications of water stress-induced changes in the levels of endogenous ascorbic acid and hydrogen peroxide in Vigna seedlings. Physiol. Plant 1983, 58, 166-170. [CrossRef]

52. Griffith, O.W. Determination of glutathione and glutathione disulfide using glutathione reductase and 2-vinylpyridine. Anal. Biochem. 1980, 106, 207-212. [CrossRef]

53. Bradford, M.M. A rapid and sensitive method for the quantitation of microgram quantities of protein utilizing the principle of protein-dye binding. Anal. Biochem. 1976, 72, 248-254. [CrossRef]

54. Kono, Y. Generation of superoxide radical during autoxidation of hydroxylamine and an assay for superoxide dismutase. Arch. Biochem. Biophys. 1978, 186, 189-195. [CrossRef]

55. Aebi, H. Catalase in vitro. Methods Enzymol. 1984, 105, 121-126. 
56. Rao, M.V.; Paliyath, G.; Ormrod, D.P. Ultraviolet-B- and ozone-induced biochemical changes in antioxidant enzymes of Arabidopsis thaliana. Plant Physiol. 1996, 110, 125-136. [CrossRef] [PubMed]

57. Shannon, M.C.; Grieve, C.M. Tolerance of vegetable crops to salinity. Sci. Hortic. 1999, 78, 5-38. [CrossRef]

58. Abd El-Mageed, T.A.; Semida, W.M.; Abd El-Wahed, M.H. Effect of mulching on plant water status, soil salinity and yield of squash under summer-fall deficit irrigation in salt affected soil. Agric. Water Manag. 2016, 173, 1-12. [CrossRef]

59. Semida, W.M.; Abd El-Mageed, T.A.; Hemida, K.; Rady, M.M. Natural bee-honey based biostimulants confer salt tolerance in onion via modulation of the antioxidant defence system. J. Hortic. Sci. Biotechnol. 2019, 94, 632-642. [CrossRef]

60. Seleiman, M.F.; Semida, W.M.; Rady, M.M.; Mohamed, G.F.; Hemida, K.A.B.A.A.; Hassan, M.M.; Shami, A. Sequential Application of Antioxidants Rectifies Ion Imbalance and Strengthens Antioxidant Systems in Salt-Stressed Cucumber. Plants 2020, 9, 1783. [CrossRef]

61. Hanin, M.; Ebel, C.; Ngom, M.; Laplaze, L.; Masmoudi, K. New insights on plant salt tolerance mechanisms and their potential use for breeding. Front. Plant Sci. 2016, 7, 1787. [CrossRef]

62. Abd El-Mageed, T.A.; Abd El-Mageed, S.A.; Semida, W.M.; Rady, M.O.A. Silicon Defensive Role in Maize (Zea mays L.) against Drought Stress and Metals-Contaminated Irrigation Water. Silicon 2020, 1-12. [CrossRef]

63. Melo, H.F.; de Souza, E.R.; Cunha, J.C. Fluorescence of chlorophyll a and photosynthetic pigments in Atriplex nummularia under abiotic stresses. Rev. Bras. Eng. Agric. Ambient. 2017, 21, 232-237. [CrossRef]

64. Rady, M.O.A.; Semida, W.M.; El-mageed, T.A.A.; Howladar, S.M.; Shaaban, A. Foliage Applied Selenium Improves Photosynthetic Efficiency, Antioxidant Potential and Wheat Productivity under Drought Stress. Int. J. Agric. Biol. 2020, 24, 1293-1300. [CrossRef]

65. Bybordi, A.; Saadat, S.; Zargaripour, P. The effect of zeolite, selenium and silicon on qualitative and quantitative traits of onion grown under salinity conditions. Arch. Agron. Soil Sci. 2018, 64, 520-530. [CrossRef]

66. Rady, M.O.A.; Semida, W.M.; Howladar, S.M.; Abd El-Mageed, T.A. Raised beds modulate physiological responses, yield and water use efficiency of wheat (Triticum aestivum L) under deficit irrigation. Agric. Water Manag. 2021, 106629. [CrossRef]

67. Abdelkhalik, A.; Pascual, B.; Nájera, I.; Domene, M.A.; Baixauli, C.; Pascual-Seva, N. Effects of deficit irrigation on the yield and irrigation water use efficiency of drip-irrigated sweet pepper (Capsicum annuum L.) under Mediterranean conditions. Irrig. Sci. 2020, 38, 89-104. [CrossRef]

68. Semida, W.M.; Taha, R.S.; Abdelhamid, M.T.; Rady, M.M. Foliar-applied $\alpha$-tocopherol enhances salt-tolerance in Vicia faba L. plants grown under saline conditions. S. Afr. J. Bot. 2014, 95, 24-31. [CrossRef]

69. Proietti, P.; Nasini, L.; Del, D.; Amato, R.D.; Tedeschini, E.; Businelli, D. Selenium protects olive (Olea europaea L.) from drought stress. Sci. Hortic. 2013, 164, 165-171. [CrossRef]

70. Yan, W.; Zhong, Y.; Shangguan, Z. A meta-analysis of leaf gas exchange and water status responses to drought. Sci. Rep. 2016, 6, 20917. [CrossRef] [PubMed]

71. Khataar, M.; Mohhamadi, M.H.; Shabani, F. Soil salinity and matric potential interaction on water use, water use efficiency and yield response factor of bean and wheat. Sci. Rep. 2018, 8, 2679. [CrossRef]

72. Abd El-Mageed, T.A.; El-Sherif, A.M.A.; Abd El-Mageed, S.A.; Abdou, N.M. A novel compost alleviate drought stress for sugar beet production grown in Cd-contaminated saline soil. Agric. Water Manag. 2019, 226, 105831. [CrossRef]

73. Ashraf, M.; Foolad, M.R. Roles of glycine betaine and proline in improving plant abiotic stress resistance. Environ. Exp. Bot. 2007, 59, 206-216. [CrossRef]

74. Khattab, H.I.; Emam, M.A.; Emam, M.M.; Helal, N.M.; Mohamed, M.R. Effect of selenium and silicon on transcription factors NAC5 and DREB2A involved in drought-responsive gene expression in rice. Biol. Plant 2014, 58, 265-273. [CrossRef]

75. Owusu-Sekyere, A.; Kontturi, J.; Hajiboland, R.; Rahmat, S.; Aliasgharzad, N.; Hartikainen, H.; Seppänen, M.M. Influence of selenium (Se) on carbohydrate metabolism, nodulation and growth in alfalfa (Medicago sativa L.). Plant Soil 2013, 373, 541-552. [CrossRef]

76. Diao, M.; Ma, L.; Wang, J.; Cui, J.; Fu, A.; Liu, H.-Y. Selenium promotes the growth and photosynthesis of tomato seedlings under salt stress by enhancing chloroplast antioxidant defense system. J. Plant Growth Regul. 2014, 33, 671-682. [CrossRef]

77. Khan, M.I.R.; Nazir, F.; Asgher, M.; Per, T.S.; Khan, N.A. Selenium and sulfur influence ethylene formation and alleviate cadmium-induced oxidative stress by improving proline and glutathione production in wheat. J. Plant Physiol. 2015, 173, 9-18. [CrossRef]

78. Abd El-Mageed, T.A.; Semida, W.M.; Rady, M.M. Moringa leaf extract as biostimulant improves water use efficiency, physiobiochemical attributes of squash plants under deficit irrigation. Agric. Water Manag. 2017, 193, 46-54. [CrossRef]

79. Hasanuzzaman, M.; Borhannuddin Bhuyan, M.H.M.; Anee, T.I.; Parvin, K.; Nahar, K.; Al Mahmud, J.; Fujita, M. Regulation of ascorbate-glutathione pathway in mitigating oxidative damage in plants under abiotic stress. Antioxidants 2019, 8, 384. [CrossRef]

80. Hasanuzzaman, M.; Hossain, M.A.; Fujita, M. Selenium-induced up-regulation of the antioxidant defense and methylglyoxal detoxification system reduces salinity-induced damage in rapeseed seedlings. Biol. Trace Elem. Res. 2011, 143, $1704-1721$. [CrossRef]

81. Mittler, R. Oxidative stress, antioxidants and stress tolerance. Trends Plant Sci. 2002, 7, 405-410. [CrossRef] 
82. Hussein, H.A.A.; Darwesh, O.M.; Mekki, B.B.; El-Hallouty, S.M. Evaluation of cytotoxicity, biochemical profile and yield components of groundnut plants treated with nano-selenium. Biotechnol. Rep. 2019, 24, e00377. [CrossRef] [PubMed]

83. Luo, H.; Wang, F.; Bai, Y.; Chen, T.; Zheng, W. Selenium nanoparticles inhibit the growth of HeLa and MDA-MB-231 cells through induction of S phase arrest. Colloids Surf. B Biointerfaces 2012, 94, 304-308. [CrossRef] [PubMed]

84. El-Ramady, H.; Faizy, S.E.D.; Abdalla, N.; Taha, H.; Domokos-Szabolcsy, É; Fari, M.; Elsakhawy, T.; Omara, A.E.D.; Shalaby, T.; Bayoumi, Y.; et al. Selenium and nano-selenium biofortification for human health: Opportunities and challenges. Soil Syst. 2020, 4, 57. [CrossRef] 